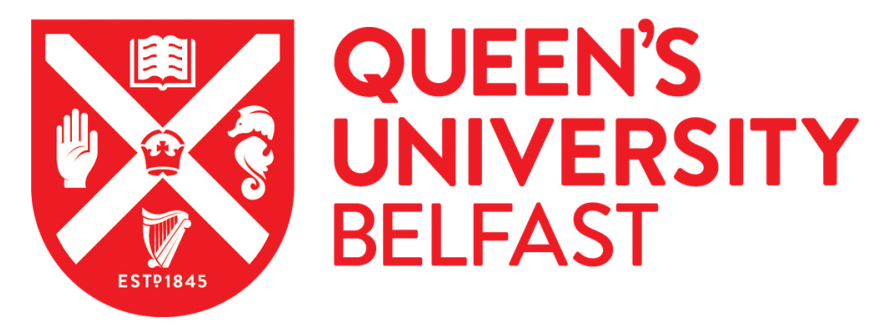

\title{
The initial, primary and secondary consolidation response of soft clay reinforced with a granular column under isolated loading
}

Sivakumar, V., Donohue, S., McKinley, J., Serridge, C., \& Tripathy, S. (2020). The initial, primary and secondary consolidation response of soft clay reinforced with a granular column under isolated loading. Géotechnique, [17P-178R1]. https://doi.org/10.1680/jgeot.17.P.178

Published in:

Géotechnique

Document Version:

Peer reviewed version

Queen's University Belfast - Research Portal:

Link to publication record in Queen's University Belfast Research Portal

Publisher rights

Copyright 219 Thomas Telford (ICE Publishing). This work is made available online in accordance with the publisher's policies. Please refer to any applicable terms of use of the publisher.

\section{General rights}

Copyright for the publications made accessible via the Queen's University Belfast Research Portal is retained by the author(s) and / or other copyright owners and it is a condition of accessing these publications that users recognise and abide by the legal requirements associated with these rights.

Take down policy

The Research Portal is Queen's institutional repository that provides access to Queen's research output. Every effort has been made to ensure that content in the Research Portal does not infringe any person's rights, or applicable UK laws. If you discover content in the Research Portal that you believe breaches copyright or violates any law, please contact openaccess@qub.ac.uk. 
The initial, primary and secondary consolidation response of soft clay reinforced with a granular column under isolated loading

Authors

V. Sivakumar (Corresponding author), Reader in Geotechnical Engineering

School of Natural and Built Environment, Queen's University Belfast, Belfast, United Kingdom. Email: v.sivakumar@qub.ac.uk

M.C. Moorhead, Programme Manager, INTO Queens, Queen's University Belfast, Belfast, United Kingdom. Email: catherine.moorhead@qub.ac.uk

S. Donohue, Associate Professor in Geotechnical Engineering, School of Civil Engineering, University College Dublin, Republic of Ireland. Email: shane.donohue@ucd.ie

C. Serridge, Chief Engineer-Ground Improvement, Balfour Beatty Ground Engineering, Chaddock Lane, Worsley, Manchester M28 1XW. Email: colin.serridge@balfourbeatty.com

S.Tripathy, Reader, School of Engineering, Cardiff University, United Kingdom. Email: TripathyS@cardiff.ac.uk

J.McKinley, Lecturer, Geotechnical Engineering, School of Natural and Built Environment, Queen's University Belfast, Belfast, United Kingdom, Email:

john.mckinley@qub.ac.uk

Contact:

$\checkmark$ Sivakumar

SNBE

Queen's University Belfast

UK

Email:v.sivakumar@qub.ac.uk 
The initial, primary and secondary consolidation response of soft clay reinforced with a granular column under isolated loading

\begin{abstract}
This paper presents the measurement and assessment of initial, consolidation and creep settlements of an isolated circular footing supported on soft clay samples reinforced with a single granular column. Clay samples (300 mm diameter, $400 \mathrm{~mm}$ high) were formed from reconstituted kaolin and remoulded sleech which is an active material, exhibiting significant creep. These samples were tested in two identical testing chambers with various features to capture the settlement under constant foundation loading and dissipation of pore water pressure.
\end{abstract}

The behaviour of a circular footing (70 $\mathrm{mm}$ in diameter) on a clay bed was observed. In one model, the footing was supported by a $40 \mathrm{~mm}$ diameter granular column formed by compacting crushed basalt in a preformed cavity. The model footings, with and without a granular column, were subjected to five vertical loading increments: $60 \mathrm{kPa}, 120 \mathrm{kPa}, 180$ $\mathrm{kPa}, 240 \mathrm{kPa}$ and $300 \mathrm{kPa}$ in the case of kaolin. Similar tests were conducted in sleech, in this case with vertical loadings of $60 \mathrm{kPa}, 120 \mathrm{kPa}$ and $180 \mathrm{kPa}$. Each test lasted approximately 10 months. In the case of kaolin, the settlement reduction factor was marginal, although it was considerably better for sleech. Kaolin exhibited marginal creep settlement under low-moderate bearing pressure, which increased substantially under high bearing pressures. Creep settlement was more prominent in sleech at all levels of bearing pressures. The very interesting finding from the investigation is that the settlement reduction factors due to consolidation and creep are similar in order under low to moderate loadings.

Key words: Consolidation, settlement, creep 


\section{INTRODUCTION}

There are several ground improvement techniques currently used in practice, with granular columns (also referred to as vibrated stone columns) being the most commonly used technique (McCabe, 2009 add Pugh, 2017). Granular columns provide a cost effective and sustainable solution, when compared to deep foundation piles (McCabe et.al. 2009; AlKhafaji and Graig, 2000; Naaajjar, 2013). Granular columns are compressible load bearing piles and they have been used to enhance the composite engineering characteristics of a range of soils including soft clays. The process involves replacing 10-35\% of the in-situ 'poor' soil with uniformly graded gravel-sized $(25-50 \mathrm{~mm})$ crushed rock (Muir Wood et.al. 2000; McKelvey et.al. 2004).

Laboratory based model studies and full-scale investigations have provided some useful information so as to understand the load carrying capacity and settlement control of such foundations. An executive summary of selected investigations is provided by Serridge, 2016, and Pugh, 2017. A classical contribution to the knowledge in this specific topic is based on the laboratory investigations carried out by Hughes and Withers, 1974. This investigation was then further developed by many others, notably Charles and Watts, 1983; Bachus and Barksdale, 1984; Narashima Roa et.al. 1992; Hu, 1995; Muir-Wood et.al. 2000; McKelvey et.al 2004; Black et.al. 2011; Shahu and Reddy, 2011; Cimentada et.al. 2014; Jeludin et.al. 2016. These investigations have been complemented with a number of field studies, both looking into bearing capacity and settlement performance (Hughes et.al., 1974; Greenwood, 1991; Bergado and Lam,1987; Cooper and Rose, 1999; Slocombe at.al. 2000; Watts et.al. 2000; Serridge, 2016) or centrifuge testing (Fragaszy and Cheney, 1981; Almeida et.al. 1985; Greenwood, 1991; Al-Khafaji and Craig, 2000; Lee et.al. 2004; Weber et.al. 2010). Numerical and empirical studies have also been carried out to validate the observed performance (Priebe, 1995; Castro and Karstunen, 2010; Sexton et.al. 2017).

Historically, granular columns have been used to support widespread loading (e.g. embankments and sub-base etc.). With increasing pressure to develop marginal soft clay sites, granular columns have had been given increasing consideration for isolated shallow footings to support low-to-moderate structural loading, depending on the strength of the in situ materials (McCabe, et.al, 2009). Further to this, the stone columns would not be used for very heavy loading unless in purely granular soils where up to $250 \mathrm{kPa}$ allowable bearing capacity can be achieved. However, in many cases the allowable bearing pressure is limited to $150 \mathrm{kPa}$ under strip or pad foundations. On the contrary, in exceptional cases, up to tenstorey buildings have been supported on ground treated with granular columns in Manchester, UK. 
Granular columns rely, at least in part, for their support on the passive resistance afforded by the surrounding soft clay soils. Applying high loading to a footing constructed over granular column reinforced soft clay soils can lead to excessive column bulging which is translated as excessive settlement at footing level. Hence, footing loadings have to be restricted, dependent upon the initial undrained shear strength of the soft clays. As the granular columns are stiffer than the native soil, the columns carry a large proportion of the foundation loading (Naaajjar, 2013; Pugh, 2017; Jeruline, et.al. 2016). When columns are formed in large numbers (i.e. raft), the interaction between the columns and the surrounding soil is effective and the performance of the column can be analysed based on a "unit cell" approach (Hughes and Withers, 1974) where the lateral expansion of the column is assumed uniform along its length. However, when small numbers of columns are used, as in the case of pad and strip footings (usually 3-5 columns), there are at least three possible modes of failure for granular columns: (a) friction failure on account of insufficient shaft resistance; (b) bulging failure, which usually occurs at the top part of the column; (c) bending and bulging failure caused by non-uniform lateral pressures, often prevailing on outer columns, Jeludine et.al. 2016. These failure modes are discussed in detail by McKelvey et.al. 2004, who investigated the interactions between granular columns and the surrounding clay using transparent oilbased fumed silica. The observations have shown the above three column-soil interaction scenarios even at bearing pressure at serviceability limits.

Isolated footings supported by stone column reinforced soft clay are normally designed to restrict total settlements to less than $25 \mathrm{~mm}$ and differential settlement (expressed as an angular distortion value) to be better than 1 in 500 , in order to meet the normal serviceability limit state (SLS) criteria. If soils are very soft and with significant secondary consolidation in the form of creep potential, the effectiveness of stone columns in reducing settlements will be significantly reduced. Most of the investigations conducted to date into the behaviour of soft clay with stone columns included have focused on their effectiveness in improving bearing capacity or reducing consolidation settlement. By nature, the stone columns accelerate consolidation, and it is possible therefore that a significant part of consolidation settlement may have completed by the end of the construction programme, which means that the magnitude of creep settlement may be a very significant contributor for postconstruction settlement consideration in deposits which exhibit strong creep potential. However, surprisingly the ability of stone columns to arrest long-term creep settlement has received little attention to date (Sexton et al. 2017). Any database on this aspect will assist in better assessing the application and suitability of stone columns in terms of achieving acceptable SLS criteria on marginal soft clay sites, improving confidence and reducing risk. 
This paper therefore aims to investigate each component of settlement (initial, consolidation and creep) with respect to granular columns, when the treated ground is subjected to isolated loading.

\section{EXPERIMENTAL PROCEDURE}

The experimental programme involved testing of two different materials: (i) kaolin, which is considered to be a non-active material, exhibiting marginal creep settlement and (ii) a post glacial estuarine soft soil, locally known as Belfast Sleech (the term "sleech" will be used in the remainder of the paper). Sleech is considered to be an active material containing organic matter and exhibiting considerable creep settlement (Glossop and Farmer, 1979; Davies and Humpheson, 1981; Lehane, 2002; Philips et.al. 2011). The aspect of creep was generally considered to be "material nature". However, Harley et.al, 2016, reported that even less creepable materials can show a significant secondary settlement under shear loading. This was therefore one of the reasons that the kaolin was also considered in the present investigation.

The investigations were carried out on $300 \mathrm{~mm}$ diameter and $400 \mathrm{~mm}$ high samples of reconstituted kaolin and remoulded sleech. These samples were prepared by onedimensional consolidation using the large consolidation chamber shown in Figure 1 (Black et.al. 2011). The seal between the consolidation chamber and the loading piston was achieved using an inflatable "O" ring. Samples of kaolin (physical properties of kaolin are listed in Table 1) were prepared by consolidating slurry prepared at $1.5 \times$ Liquid Limit, representing a targeted moisture content of $105 \%$. The slurry was subsequently consolidated to a vertical effective stress of $200 \mathrm{kPa}$. In the case of sleech, a large amount of material was excavated from a site close to the City Airport, Belfast, Northern Ireland. This soil is generally described as a soft grey silty clay and the relevant physical properties are listed in Table 1. Unlike kaolin, this material was remoulded at its natural water content (approximately $38 \%$, based on random sampling of the sleech) and carefully kneaded into the consolidation chamber. The clay bed was then subjected to a vertical effective stress of $200 \mathrm{kPa}$. In order to reduce consolidation time, the bottom part of the consolidation chamber (just under 400 $\mathrm{mm}$ long) was fitted with filter strips, embedded in the cylindrical surface. This approach has significantly reduced the consolidation time for kaolin when compared with the observations reported by Black at.al. 2011.

Upon consolidation, the sample was extruded from the consolidation chamber and located directly on the testing chamber, Figure $1 \mathrm{~b}$. The sample was then trimmed to a height of 400 $\mathrm{mm}$. The trimmings of the samples (including the spoil derived from boring a hole for 
installing the granular column) were used initially for assessing the void ratio distribution. The variation in the average void ratio of the sleech was approximately $1.00 \pm 0.01$ and that for kaolin was $1.38 \pm 0.03$. The sample was enclosed in a rubber membrane and a footing was carefully located on the inner annulus of the top flexible membrane. This specially manufactured rubber membrane was employed in order to model near-field conditions such as flexible boundary conditions away from the isolated footing. A graphical illustration of the footing arrangement is presented in Figure 2. The inner wall of the membrane was sealed against the footing and the outer wall was sealed against a metal ring. Drainage of the sample was allowed from the bottom of the sample and through an outlet located on the flexible top membrane. Under the top drainage line, a small cavity was formed on the clay bed and filled with fine gravel. Two layers of filter paper were located at the top of the sample to facilitate the free drainage of water. In the case of the sleech samples, the pore water pressure was measured close to the footing location $(15 \mathrm{~mm}$ away from footing and $15 \mathrm{~mm}$ below the top of the sample), by inserting a pore water pressure probe through another outlet located in the top rubber membrane (Figure 2). Identical measurements were attempted in the kaolin (tested in a separate, but identical testing chamber). However, the pore water probe got damaged and replacement was not possible due to cost implications). A simplified version of the complete test set-up is shown in Figure 3. Settlement was measured at two locations using internal displacement gauges (Linear Voltage Differential Transducer, LVDT), on the footing itself (LVDT 1) and at a point $135 \mathrm{~mm}$ away from the centre of the footing (LVDT 2). Ideally LVDT 2 should have been placed at least 5 times the diameter of the footing away to avoid the zone of influence upon foundation loading. However, it was not possible in the present study as the diameter of the sample was only $300 \mathrm{~mm}$. Data reported later seems to suggest that the measurements taken from LVDT 2 were not significantly affected by the foundation loading.

The tests carried out were on unreinforced and reinforced clay beds. In the case of the unreinforced clay bed, the sample of kaolin was saturated and consolidated to an effective confining pressure of $100 \mathrm{kPa}$ (back pore water pressure $200 \mathrm{kPa}$ and confining pressure $300 \mathrm{kPa}$ ). Moorhead, 2013, reported that consolidation and creep settlement reduction factors were strongly influenced by the overconsolidation ratio. Therefore, for the sample of sleech, the effective consolidation pressure was kept at $50 \mathrm{kPa}$, to make it more overconsolidated than the sample of kaolin. During this consolidation process a small amount of footing pressure (10 $\mathrm{kPa}$ ) was applied in order to avoid any initial bedding-in errors. Upon completion of consolidation, the foundation pressures were increased to 60 $\mathrm{kPa}, 120 \mathrm{kPa}, 180 \mathrm{kPa}, 240 \mathrm{kPa}$ and $300 \mathrm{kPa}$ in the case of kaolin. For the sleech, the test was terminated at a foundation pressure of $180 \mathrm{kPa}$. Each loading stage lasted between 6- 
10 weeks. The footing load was applied using an actuator and maintained constant using a feed-back system between the internal load cell and an automated loading controller.

In the case of the reinforced clay bed, after consolidation to $100 \mathrm{kPa}$ or $50 \mathrm{kPa}$ of effective stresses (respectively for kaolin and sleech) the confining pressures were removed under undrained conditions and an auger was used to form a cavity $(40 \mathrm{~mm}$ diameter, $400 \mathrm{~mm}$ long) in the sample. A granular column was formed in the cavity, using crushed basalt (D10 $=2.3 \mathrm{~mm} ; \mathrm{D} 30=2.8 \mathrm{~mm}$ and $\mathrm{D} 60=3.1 \mathrm{~mm}$ with a uniformity coefficient, $U$, (D60/D10) of $\approx 1.5)$, giving an area replacement ratio, $A_{s}$ of $33 \%\left(A_{s}=A_{c} / A_{f}\right.$, where $A_{c}$ and $A_{f}$ are the area of the column and footing and the relevant diameters are $40 \mathrm{~mm}$ and $70 \mathrm{~mm}$ respectively). In practice, it is common to use uniformly graded basalt with D10, D30 and D60 equivalent to $30 \mathrm{~mm}, 37.5 \mathrm{~mm}$ and $45 \mathrm{~mm}$ corresponding to a 15 fold reduction in comparison to the column material that was used in the laboratory study. This ratio also corresponds reasonably well with the diameter of the column used in practice. The average column density was $1.67 \mathrm{Mg} / \mathrm{m}^{3}$. The column was inundated with water by flushing water from the base of the column and flushing from the top. The external pressures were reapplied, and the sample was saturated and again consolidated to the target effective stresses (100 kPa or $50 \mathrm{kPa}$ respectively for kaolin and sleech) prior to foundation loading. The magnitude of foundation loading applied was the same as for the unreinforced clay bed samples. The method of column installation adopted in the present research is best described as the "replacement method" however, in field applications, often the process is displacement. Jeludine et.al, 2016, examined this aspect using physical model tests and concluded that columns installed using the displacement method performed marginally better than those installed using the replacement method.

\section{RESULTS AND DISCUSSION}

There are many hypotheses existing in literature in relation to creep settlement. The generally accepted view is that creep settlement follows after the dissipation of excess pore water pressure. An opposing argument is that the creep settlement begins as soon as the loading regime is changed. However adopting the latter approach may pose difficulties in determining the consolidation settlement in the present investigations. Therefore, for simplicity it is assumed that creep settlement becomes more pronounced towards the end of the consolidation stage. In this research, the initial, consolidation and creep settlements were examined when the foundation was subjected to bearing pressures of $60 \mathrm{kPa}, 120 \mathrm{kPa}, 180$ $\mathrm{kPa}$ in the case of kaolin and sleech, with additional loading increments of $240 \mathrm{kPa}$ and 300 $\mathrm{kPa}$ in the case of kaolin. The observed performances are interpreted in the following manner: 


$$
\begin{array}{ll}
\Delta s_{i(n c)} \text { or } \Delta s_{i(c)} & \text { Equ 1 } \\
\Delta s_{c(n c)} \text { or } \Delta s_{c(c)} & \text { Equ 2 } \\
n_{i}=\Delta s_{i(n c)} / \Delta s_{i(c)} & \text { Equ 3 } \\
n_{c}=\Delta s_{c(n c)} / \Delta s_{c(c)} & \text { Equ 4 } \\
c_{\alpha(n c)} \text { or } c_{\alpha(c)}=\frac{\Delta \varepsilon_{\alpha} \times 100}{\Delta \log (t)} \% & \text { Equ 5 } \\
n_{\alpha}=c_{\alpha(n c)} / c_{\alpha(c)} & \text { Equ 6 }
\end{array}
$$

where subscript $\Delta \mathrm{s}$ is settilment, " $n c$ " stands for no columns and " $c$ " stands for clay with columns included. The additional terms are: creep strain $\Delta \varepsilon_{\alpha}$, and time $\Delta \log (t)$. Note here that the creep rate is defined in terms of strain, assuming the creep takes place along the entire thickness of the clay, however, this is a simplified assumption as under the footing the stress level changes with depth and therefore the creep rate also will change. This assumption will become oversimplified if the clay immediately below the footing is normally consolidated and further below the footing (away from the stress bulb) is still in overconsolidated state. The approach is, however, considered acceptable to initiate the discussions, although a different approach is considered later in this article.

As discussed above, foundation loading will result in: (a) initial settlement that may take place in a short period of time; (b) consolidation settlement, which may occur for several weeks depending on the soil type, and (c) creep settlement which is also strongly timedependent. As stated earlier, for simplicity it was assumed that the creep settlement begins after the completion of consolidation settlement. However identifying the end of consolidation settlement was difficult at small foundation loading (even under one-dimensional loading conditions as reported by Moorhead, 2013). Such difficulties could be annihilated if pore water pressure measurements were taken during the consolidation period and creep phases (Moorhead, 2013). In the case of testing on kaolin, the pore water pressure sensor became faulty and therefore valuable information on the dissipation of excess pore water pressures could not be obtained. However, in the sleech, such information was obtained using the pore water pressure sensor. In the case of the sleech, the settlement-time relationships at all three loading stages, were rather complex and employing Casagrande's (Casagrande, 1936) approach for delineating the beginning of creep phase was difficult. Therefore, the information on the dissipation of excess pore water pressure was used as a tool to segregate the consolidation and creep settlements phases. Kaolin, though, exhibited typical "S" shape settlement-time relationships at moderate to high loading, which assisted the segregation of 
the consolidation and creep settlements. However, at low loading the issue of identifying the end of the consolidation stage was still difficult and therefore as an approximation it was assumed that the consolidation phase terminates at the same time as observed in the case of moderate to high loading. The authors accept that it is a significant assumption.

Typical cases for estimating the beginning of consolidation (degree of consolidation $U=0 \%$ ) and the end of consolidation (degree of consolidation $U=100 \%$ ) are depicted in Figures 4, 5 , 6 and 8 . In the case of kaolin (Figures 4 and 5), at high loading Casagrande's approach was adopted to identify $U=0 \%$ and $U=100 \%$. The graphical constructions are indicated by $A A$ and $\mathrm{BB}$ at $300 \mathrm{kPa}$ of bearing pressure and $\mathrm{A}^{\prime} \mathrm{A}^{\prime}$ and $\mathrm{B}^{\prime} \mathrm{B}^{\prime}$ at $240 \mathrm{kPa}$ of bearing pressure. $\mathrm{A}$ similar approach was not possible at low bearing pressures. Since the time required for $\mathrm{U}=100 \%$ is not significantly affected by the bearing pressures of 240 and $300 \mathrm{kPa}$, it was assumed that primary consolidation ends at the same time at all three other stages of loading. The initial settlement was assessed by looking at the settlement at time " $\mathrm{t}$ " and at time " $4 \mathrm{t}$ " at the beginning of the consolidation process. The relevant constructions are shown in Figures 4,5,6 and 8. In the case of sleech, the "S" shaped curve was not prevalent at any of the loading stages. However, the pore water pressure sensor buried close to the footing provided reasonable information as to the termination of primary consolidation. Careful assessment of the data shown in Figures 7 and 9 indicated that the time required for completion of primary consolidation was generally similar at all three stages of loading. Therefore, this time was used as a tool to delineate the primary consolidation settlement at all three stages of loading. The information presented hereafter is based on the assessment carried out on the settlement-time curve using the procedure described above.

The initial and consolidation settlements are more pronounced in the stress zone that develops under the footing. However, the entire clay bed will experience creep settlement caused by the initial consolidation of the sample to $50 \mathrm{kPa}$ in the case of sleech and $100 \mathrm{kPa}$ in the case of kaolin. This may pose a complexity in determining the consolidation settlement of the footing, as it may also contain a proportion of creep settlement of the entire clay below the active stress bulb. In order to isolate this, the settlement of the footing was analysed with respect to the settlement of the surrounding clay bed (measurements were taken $135 \mathrm{~mm}$ away from the centre of the footing at LVDT-2), which is undergoing creep settlement under the relevant effective confining pressures.

Kaolin: Figure 4a shows the net settlement (with respect to the settlement of the clay bed away from the foundation) of the footing plotted against log time (in hours) under a foundation loading of $60-300 \mathrm{kPa}$ in increments of $60 \mathrm{kPa}$. Each loading stage was 
maintained for 6-8 weeks to allow all three stages of settlement to develop fully. The settlement of the clay bed away from the footing (135mm away from the centre of footing) is shown in Figure 4b. There appears to be initial, consolidation and creep settlements, however, the clay bed was undergoing creep throughout all five loading stages, as no significant stress changes took place at the location where the settlement of the clay bed was measured. The two broken lines (extreme cases), shown in Figure 4b, indicate the slope of the creep lines away from the footing. The estimated creep rate $c_{\alpha(n c a)}$ (nca refers to no column, away from footing) of the clay bed away from the foundation loading, as defined in Equ 5 , is approximately $0.013 \pm 0.007 \%$ and it is generally unaffected by the foundation loading. The clay bed is in a slightly overconsolidated state (i.e. initially consolidated to 200 $\mathrm{kPa}$ of vertical effective stress in the consolidation chamber and subsequently consolidated in the testing chamber to $100 \mathrm{kPa}$ effective stress under isotropic stress conditions) and therefore the creep rates are expected to be small. However, the creep rate observed in the case of one-dimensional consolidation tests carried out in a Rowe Cell, reported by Moorhead, 2013, is approximately $0.11 \%$ for overconsolidated kaolin under the same stress level, which is significantly higher than the value obtained on the clay bed, away from the footing subjected at the same stress level but under isotropic stress conditions. This implies that the creep rate is also affected by the loading conditions, i.e. one-dimensional or isotropic.

The time at which the consolidation settlement terminates is indicated, in Figure $4 \mathrm{a}$, by a circular data point. The relevant initial $\Delta s_{i(n c)}$ and consolidation $\Delta s_{c(n c)}$ settlements of the footing and the creep rate, $c_{\alpha(n c)}$ as defined by Equ 5, under the footing, was determined based on the slope of the settlement curve at the tail, assuming that creep is uniform along the length of the sample. The relevant graphical constructions are shown in Figure 4a. The construction used for determining $100 \%$ consolidation is indicated in Figure $4 \mathrm{a}$, for foundation loadings of 240 and $300 \mathrm{kPa}$. This took place after approximately 200 hours of the initial loading. As the " $S$ " shaped curve is not obvious at low loading, it was also assumed that consolidation terminates after approximately 200 hours for other footing pressures. The initial settlements, $\Delta s_{i(n c)}$ upon the application of foundation loading are $0.03,0.04,0.04$, 0.08 and $0.10 \mathrm{~mm}$ under foundation pressures of $60,120,180,240$ and $300 \mathrm{kPa}$ respectively. The consolidation settlements $\Delta s_{c(n c)}$ for the relevant loading stages are 0.32 , $0.46,0.95,1.97$, and $3.46 \mathrm{~mm}$ respectively for the loading stages listed above. Note that the initial settlement has been deducted when calculating the consolidation settlement. The creep rates, $c_{\alpha(n c)}$ as defined by Equ 5 are $0.035,0.053,0.063,0.123$ and $0.150 \%$ respectively for the same loading stages (Table 2 ). 
Figures $5 \mathrm{a}$ shows the net settlement of the footing plotted against log time (in hours) for kaolin reinforced with a fully penetrating, $40 \mathrm{~mm}$ diameter column under a foundation loading of $60-300 \mathrm{kPa}$ in increments of $60 \mathrm{kPa}$. The settlement of the clay bed away from the footing is shown in Figure $5 \mathrm{~b}$, for each footing load stage. The creep rate away from footing $c_{\alpha(c a)}$ is approximately $0.012 \%$ and unaffected by the foundation loading, but the value is similar to the creep rate evaluated for the unreinforced clay bed. The time at which the consolidation settlement terminates is indicated, in Figure $5 \mathrm{a}$, by circular data points and it was just over 40 hours as opposed to 200 hours in the case where the clay bed did not have a granular column included (Figure 4a), resulting in reduction of consolidation time of 5 fold. This reduction in consolidation time is also in agreement with the observations reported by Moorhead, 2013, where the investigation was carried out under one-dimensional loading conditions.

The initial settlements, $\Delta s_{i(c)}$ upon application of foundation loading are $0.17,0.25,0.25$, 0.12 and $0.10 \mathrm{~mm}$ under foundation pressures of $60,120,180,240$ and $300 \mathrm{kPa}$ respectively. The consolidation settlements $\Delta s_{c(c)}$ for the relevant loading stages are 0.21 , $0.35,0.73,1.16$, and $1.75 \mathrm{~mm}$ respectively for the loading stages listed above. The creep rates, $c_{\alpha(c)}$ as defined by Equ 5 are $0.044,0.037,0.050,0.078$ and $0.125 \%$ respectively for the same loading stages (Table 2). The initial settlements (Table 2) following application of foundation loading are significant when compared with the unreinforced clay bed. Similar observations were also reported by Watts et.al., 2000, and Serridger, 2016, based on field observations. For this reason, the initial settlement improvement factor $n_{i}$ is not reported in Table 2. The settlement improvement factor $n_{c}$ (defined in Equation 4) was determined for each load stage and the values are 1.52, 1.31, 1.30, 1.69, and 1.97 in order of load stage. These findings suggest that the inclusion of a granular column resulted in an average settlement improvement factor of 1.56 which is considered to be marginal. Similar settlement improvement factors are also been reported by McCabe et.al., 2009, and Serridge, 2016, under isolated loading conditions, where both are based on field observations. The creep rates $c_{\alpha(c)}$ are $0.044,0.037,0.050,0.078$ and $0.125 \%$ under foundation loading of 120,180 , 240 and $300 \mathrm{kPa}$ respectively. The creep improvement factor, $n_{\alpha}$ was used to quantify the effectiveness of granular columns for containing creep settlement and the relevant values are $0.80,1.40,1.25,1.58$ and 1.2 with an average value of 1.24. As observed, the benefit of using granular columns for containing creep settlement appears to be marginal but in the same order as the settlement improvement factor due to consolidation as a first approximation. 
Sleech: Some interesting observations were made from the investigations carried out on a

The completion of consolidation and commencement of creep was estimated from Figure $6(\mathrm{a})$, based on the duration for complete dissipation of pore water pressure, indicated by circular data points. The initial settlements, $\Delta s_{i(n c)}$, upon application of foundation pressures of 60,120 and $180 \mathrm{kPa}$, are $0.11,0.120$, and $0.140 \mathrm{~mm}$ respectively. The consolidation settlements $\Delta s_{c(n c)}$ for these loading stages are 1.21, 1.21 and $2.28 \mathrm{~mm}$ respectively. Note that both the creep rates and the consolidation settlements were evaluated with respect to the settlement of the clay bed away from the footing, implying that these settlements are caused by the foundation loading only. The estimated creep rates $c_{\alpha(n c)}$ are $0.163,0.200$ and $0.313 \%$ respectively for $60 \mathrm{kPa}, 120 \mathrm{kPa}$ and $180 \mathrm{kPa}$ of bearing pressure (Table 2). The creep rate away from the footing $c_{\alpha(n c a)}$ has an average value of $0.18 \%$ (Figure $6 \mathrm{~b}$ ).

Figure $8 \mathrm{a}$ shows the net settlement of the footing plotted against log time (in hours) for sleech, reinforced with a single $40 \mathrm{~mm}$ diameter, fully penetrating column, under foundation pressures of $60-180 \mathrm{kPa}$, in increments of $60 \mathrm{kPa}$. The settlement of the clay bed away from the footing is shown in Figure $8 \mathrm{~b}$. The average creep rate of the clay bed away from the footing is $0.10 \%$ and slightly lower value than that obtained on the unreinforced clay bed. The pore water pressure response from the probe buried away from the footing is shown in 
Figure 9. The average excess pore water pressure generated by the foundation loading was about $6 \mathrm{kPa}$, noticeably lower than the excess pore water pressure recorded for the unreinforced clay bed. This supports the fact that some of the loading applied on the clay bed was taken by the granular column. It also appears that the time for complete dissipation of excess pore water pressure was the same at all three loading stages (approximately 70hours). Again, the presence of the granular column has reduced the consolidation time approximately 6 fold, which is in agreement with the tests carried out on kaolin.

The initial settlements $\Delta s_{i(c)}$ upon the application of foundation loading are $0.06,0.07$ and $0.08 \mathrm{~mm}$ under foundation pressures of 60,120 and $180 \mathrm{kPa}$ respectively. The consolidation settlements $\Delta s_{c(n c)}$ are $0.49,0.51$ and $0.60 \mathrm{~mm}$ respectively for the same loading stages. The settlement improvement, $n_{c}$, was determined for each load stages and the relevant values are $2.47,2.37$ and 3.63 respectively (average value of 2.82), for applied foundation pressures of $60 \mathrm{kPa}, 120 \mathrm{kPa}$ and $180 \mathrm{kPa}$. These findings suggest that the inclusion of a granular column resulted in more than a two-fold reduction in the consolidation settlement, regardless of load stage. At each of the foundation loading stages, the creep rates, $c_{\alpha(c)}$, are $0.044,0.056$ and $0.103 \%$, respectively, The creep improvement factors, $n_{\alpha}$, for the relevant loading stages are 3.71, 3.55 and 3.05, with an average value of 3.4. These values imply that the degree to which granular columns arrest creep is significant and in alignment with the settlement improvement factors due to consolidation.

Evaluation: The present research considered the effectiveness of granular columns for controlling the three components of settlement: initial, consolidation and creep. There are several studies reported in literature in relation to settlement control, as outlined in the earlier part of this article. Many other studies were carried out under uncontrolled conditions, where provisions were not made to allow for dissipation of excess pore water pressure generated by foundation loading. In such cases, the penetration of the footing into the clay bed underneath cannot be regarded as "settlement" and, therefore, it is not possible to separate the settlement components. In the research reported here, an attempt was made to allow the settlement to develop over time under constant foundation loading under near-realistic boundary conditions. The lateral boundary conditions and the soil bed away from the foundation loading were made flexible to simulate field conditions. However, it was not possible to fully represent field conditions where the vertical stress increases with depth.

Unreinforced (i.e. without granular columns) kaolin and sleech clay beds exhibited a small amount of initial settlement upon the application of the load. However, the initial settlements 
were higher when granular columns were installed, in particular for kaolin. The increase in initial settlement was possibly caused by disturbances during the column installation process. The clay beds were levelled at the top surface upon the installation of the column and subsequently saturated and re-consolidated under the required cell and back pore water pressures, prior to foundation loading. It is possible that the clay surrounding the column may have settled more than the granular column (in particular kaolin), leaving the column protruding a small height above the clay surface, even though an additional $10 \mathrm{kPa}$ of bearing pressure was applied during the consolidation stage to avoid bedding-in error. This could have contributed to the additional initial settlement observed.

Figure 10 shows the consolidation and creep settlement improvement factors for both kaolin and sleech samples. The consolidation settlement improvement factors $n_{c}$ for kaolin are as low as 1.30 under low-to-moderate loading with higher factors observed under higher loading with an average value of 1.56 . These observations also agree favourably with the data reported by Jeludine et.al, 2016, (also included in Figure 10), who carried out investigations on settlement control using granular columns under similar test conditions in kaolin using a laboratory model study. However, in the investigation by Jeludin et. al., 2016, the foundation loading was applied slowly and continuously, without any attempt to determine the three settlement components. The settlement improvement factor for sleech is however a significantly higher than that of kaolin.

It is perhaps surprising that the settlement improvement factors $n_{a}$ or $n_{\alpha}$ due to consolidation or creep are not significantly improved in the case of kaolin, but on average the reduction factors due to both consolidation and creep are in the same order of magnitude as a first approximation. In the case of sleech, significant improvement factors of $n_{c}$, and $n_{\alpha}$ were noted, which also agrees with the findings reported by Moorhead, 2013. The kaolin clay bed was vertically consolidated to $200 \mathrm{kPa}$ and subsequently consolidated to an effective stress of $100 \mathrm{kPa}$ under isotropic stress conditions. Therefore, with the exception of the $1^{\text {st }}$ loading stage (i.e. $60 \mathrm{kPa}$ ), the clay under the footing was normally consolidated. In the case of sleech, the clay bed was consolidated to an effective vertical pressure of $200 \mathrm{kPa}$ and subsequently isotropically consolidated to an effective stress of $50 \mathrm{kPa}$, leaving the clay bed in an overconsolidated state. The sleech clay bed was subjected to three loading stages up to a maximum value of $180 \mathrm{kPa}$. Only in the final loading stage did the total vertical pressure under the footing exceed the previous stress history. Therefore, as reported by Moorhead, 2013, granular columns yield better settlement control when the soil is overconsolidated. This is also reflected in the settlement reduction factor $n_{\alpha}$ due to creep. However, a potential 
counter-argument to this is that the kaolin bed under $300 \mathrm{kPa}$ of bearing pressure resulted in a better settlement improvement factor due to consolidation. This aspect may need further investigation.

Figure 11 shows the vertical pressure distributions under the footing for the kaolin and sleech clay beds. The vertical lines represent the previous maximum pressure experienced. The vertical pressure distribution was estimated assuming a simple 2:1 spread. As discussed previously, the creep rates reported in Tables 2 were calculated based on the assumption that creep takes place along the entire length. However, the settlement of the footing was calculated with respect to the creep settlement of the clay bed far away from the footing, which was significant in the case of sleech. Therefore, any creep settlement observed under the footing, as reported in Figures 4, 5, 6 and 8 were entirely due to the foundation loading. As shown in Figure 11, the net increase in the footing pressure below $2 \times \phi$ ( $\phi$ is the diameter of the footing) is negligible. However, the assumption of a $2: 1$ load spread may be misleading in the case of a clay bed with a granular column, where the granular column takes a larger proportion of the loading. In effect the load may then be transferred to the clay bed to a considerable depth, at least $6 \times \phi(240 \mathrm{~mm}$ from the top of the clay bed, Black et. al., 2011). Therefore, the approach adopted here is simplified, but to help further evaluation of the data. The creep rates were revised assuming that creep occurs under the footing to a depth of $140 \mathrm{~mm}(\phi=70 \mathrm{~mm})$. Figure 12 shows the revised creep rate plotted against vertical pressure (which includes the vertical pressure acting on the clay due to a confining pressure of $100 \mathrm{kPa}$ for kaolin and $50 \mathrm{kPa}$ for sleech). Also included in the figures are: (a) uncorrected creep rates with and without columns, (b) creep rates reported by Moorhead, 2013, on normally consolidated and overconsolidated clay beds on both kaolin and sleech without granular columns and (c) creep rates away from the clay bed (average value during the 5 stages of loading for kaolin and 3 stages of loading for sleech, indicated by star data points).

As shown in Figure 12, the creep rates for both kaolin and sleech away from the footing, are lower than the rate established from Rowe Cell testing (Moorhead, 2013) under similar stress conditions (i.e. the stress history), suggesting that the creep rate is influenced by the nature of the loading conditions, i.e. one-dimensional or isotropic. The vertical lines in Figure 12 refer to the maximum pressure that the sample experienced during formation. In the case of kaolin, it appears that the corrected creep rates (both with and without columns) are much higher than the rates reported for normally consolidated kaolin under one dimensional loading conditions, without a column (Rowe Cell, Moorhead, 2013) under moderate to high 
foundation pressures. However, in the case of sleech, the corrected creep rates, without a column, for the first two loading stages agree with the rates determined from Rowe Cell consolidation on overconsolidated sleech (without a column). The agreement is also good during the third stage of loading, whereby the clay under the footing to a depth of approximately $2 \times \phi$ now becomes normally consolidated (Figure 12b). The observations reported above may therefore be queried as to why the corrected creep rate was higher than would typically be expected for normally consolidated kaolin. It is suggested that the reason for this is due to the additional creep associated with shear loading. This hypothesis is supported by recent work carried out on glacial till (Harley et. al. 2016), where samples were subjected to fully drained loading to a deviator stress $80 \%$ and $90 \%$ of the failure deviator stress. There was overwhelming evidence to suggest that the soil continued to deform under constant deviator stress, and that strain is referred to as creep due to shear loading. Very much similar conditions prevailed in the present investigation, particularly in the case of kaolin under higher loadings. It is possible that the foundation loading may have gone beyond the serviceability limit.

On the aspect of practical application of the present work, the research has shown some mixed, but helpful information on both settlement and creep improvement factors upon using a granular column for improving geotechnical performance. It is clear that the settlements due to both consolidation and creep cannot be contained in a significant manner in normally consolidated soils, where the term "normally consolidated" soils means really soft clays. However, the benefit of having granular columns to arrest both consolidation and creep settlements is more pronounced in overconsolidated soils (but it does not mean that the soil is referred to as stiff). In both soil types, the settlement improvement factors due to consolidation and creep are generally comparable on average and as a first approximation. Therefore this should be considered as a first stage of approximation in evaluating creep settlements to satisfy the serviceability criteria, in any soils regardless of whether they have significant creep potential.

\section{CONCLUSION}

Settlement is essentially a time-dependant process, consisting of initial, consolidation and creep settlement stages. Historically, granular columns have been used to support widespread loading, however, in recent times the use of granular columns has been extended to isolated loading such as under pad or strip footings or under floor slabs. However existing literature on how and to what extent the granular columns would reduce the initial, consolidation and creep settlement is limited. As part of the investigations, a 
comprehensive experimental programme was undertaken in order to examine the three components of settlement. Tests were carried out on samples (300 mm diameter and 400 $\mathrm{mm}$ length) of kaolin and sleech (sleech being considered as "highly creepable" soil). Samples with and without a granular column were subjected to isolated loading while maintaining flexible boundary conditions away from the footing.

The observations have shown that the presence of a granular column reduced the consolidation time by several fold which was independently validated with the dissipation of pore water pressure near the footing. The presence of a granular column also reduced the magnitude of excess pore water pressure developed upon foundation loading. The settlement improvement factors in relation to primary consolidation and creep were not significant in the case of kaolin, however they were considered to be significant in the case of sleech, which confirms that the granular columns are more effective if the clay surrounding the column is in an overconsolidated state. The rate of creep was significantly high for kaolin, under higher foundation load. This is thought to be caused by additional creep induced by shear loading.

\section{REFERENCE}

Al-Khafaji, Z. and Craig, W.H. (2000). 'Drainage and reinforcement of soft clay tank foundation by sand columns'. In Geotechnique, 50(6), pp. 709-713.

Al-Khafaji, Z. and Craig, W.H. (2000). 'Drainage and reinforcement of soft clay tank foundation by sand columns'. In Geotechnique, 50(6), pp. 709-713.

Almeida, M. S., Davies, M.C. and Parry, R.H. (1985). 'Centrifuge tests of embankments on strengthened and unstrengthened clay foundations'. In: Geotechnique, 35(4), pp. 425-441.

Bachus, R.C. and Barksdale, R.D. (1984). 'Vertical and lateral behaviour of model stone columns'. In: Proc. Intl. Conf. on in situ Soil and Rock Reinforcement, Paris, pp 99104.

Bergado, D.T. and Lam, F.L. (1987). 'Full scale load test of granular piles with different densities and different proportions of gravel and sand on soft Bangkok clay.' In: Soils and Foundation journal, 27(1), pp. 86-93

Black, A.J., Sivakumar, V. and Bell, A. (2011). The settlement performance of stone column foundations. Géotechnique 61: 909-922.

Casagrande, A. (1936). 'The determination of the pre-consolidation load and its practical Significance', In: Proc. 1st International Conf. on Soil Mechanics, Cambridge, Vol. 3. 
Castro, J. and Karstunen, M. (2010). 'Numerical simulations of stone column installation'. In: Canadian Geotechnical Journal, 47, pp. 1127-1138.

Charles, J.A. and Watts, K.S. (1983). 'Compressibility of soft clay reinforced with granular columns'. In: Proc. $8^{\text {th }}$ European Conf. on Soil Mechanics and Foundation Engineering, Helsinki, pp. 347-352.

Cimentada, A., Almudena, D.C., Jorge, C. and Cesar, D. (2011). Laboratory study on radial consolidation and deformation in clay reinforced with stone columns. Canadian Geotechnical Journal 48(1): 36-52. column foundations. Géotechnique, 61 (11), 909-922.

Cooper, M.R. and Rose, A.N. (1999). 'Stone column support for an embankment on deep alluvial soils'. In: Geotechnical Engineering, 137(1), pp.15-25.

Davies, J.A. and Humpheson, C. (1981). 'A comparison between the performance of two types of vertical drain beneath a trial embankment in Belfast'. In: Geotechnique, 31(1), pp19-31.

Fragaszy, R.J. and Cheney, J.A. (1981). 'Drum centrifuge studies of over consolidated slopes'. In: Journal of the Geotechnical Engineering Division, 107 (7), pp. 843-858.

Glossop, N.H. and Farmer, I.W. (1979). 'Settlement associated with removal of compressed air pressure during tunnelling in alluvial clay’. In: Geotechnique, 29(21), pp. 67-72.

Greenwood D.A. (1991) Load tests on stone columns. Deep Foundations and Improvements, Design, Construction and Testing, Philadelphia: ASTM STP 1089. pp. 148-171.

Harley, R.; Sivakumar, V.; Hughes, D.; Donohue, S (2016). Strength reduction of till under dynamic pore pressure condition. Geotechnique Letters, Vol. 6, No. 1, 03.2016, p. 83-88

Hu W. (1995). 'Physical Modelling of Group Behaviour of Stone Column Foundations'. PhD thesis, University of Glasgow, Glasgow.

Hughes, J.M.O. and Withers, N.J. (1974). 'Reinforcing of soft cohesive soils with stone columns'. In: Ground Engineering, 2, pp. 42-49.

Jeludine,D.K.N.M.PG, Sivakumar,V., O'Kelly,B.C. and Mackinnon (2016). Experimental observations of footing supported on soft clay reinforced with granular columns: Laboratory model study. J. Geotech and Geoenvironmental Engineering, 142(1).

Lee, F.H., Juneja, A. and Tan, T.S. (2004). 'Stress and pore pressure changes due to sand compaction pile installation in soft clay'. In: Geotechnique, 54(1), pp. 1-16.

Lehane, B.M. (2002). 'Vertically loaded shallow foundation on soft clayey silt'. In: Geotechnical Engineering, 156(1), pp 17-26. 
McCabe, B.A., Nimmons, G.J. and Egan, D. (2009) A review of field performance of stone columns in soft soils. Proceedings of the ICE, Geotechnical Engineering 162(6): 323334.

McKelvey, D., Sivakumar, V., Bell A. and Graham, J. (2004) Modelling vibrated stone columns in soft clay. Proceedings of the ICE, Geotechnical Engineering 157(3): 137149.

Moorhead, M. C. (2013). Effectiveness of Granular Columns for Containing Settlement of Foundations Supported on Soft Clay. PhD Thesis, The Queen's University, Belfast

Muir Wood, D., Hu, W. and Nash, D.F.T. (2000) Group effects in stone column foundations: model tests. Géotechnique 50(6): 689-698.

Naaajjar, S.S. 2013. A State-of-the-Art Review of Stone/Sand-Column Reinforced Clay Systems. Geotechnical and Geological Engineering, Vo. No. 2 pp 355-386.

Narasimha Rao S., Prasad, C.V., Prasad, Y.V.S.N. \& Hanumanta Rao, V (1992). 'Use of stone columns in soft marine clays'. In: Proc. Canadian Geotechnical Conf., Toronto, pp. 1-7.

Phillips, D.H., G. Sinnathamby, M.I Russell, C. Anderson, and A. Pasky. 2011. Mineralogy of selected geological deposits from the Republic of Ireland and the United Kingdom for possible use as landfill capping materials for low-level radioactive waste facilities. Appl. Clay Sci.53:395-401.

Priebe H.J. (1995). 'The design of vibro replacement'. In: Ground Engineering, 28 (10), pp. 31-37.

Pugh. R., 2017. Settlement of floor slabs on stone columns in very soft clays. Proceedings of the Institution of Civil Engineers - Geotechnical Engineering, Proceedings of the Institution of Civil Engineers 170(1): 16-26,

Serridge, C.J.,2016. Briefing; The importance of field-based vibro stone column research, Ground Improvement, Proceedings of the Institution of Civil Engineers, Vol. 169, No 4, 253-263

Sexton,B.G., Sivakumar, V. McCabe,B. 2017. Creep improvement factors for vibroreplacement, design. Proceedings of the Institution of Civil Engineers - Ground Improvement, 170(1), pp 35-56.

Shahu, T. and Reddy, R.Y. (2011). Clayey soil reinforced with stone column group; Model tests and analyses. Journal of Geotechnical and Geoenvironmental Engineering, Vol 137, No 12.

Sivakumar, V., Moorhead, M. C, Donohue, S. Serridge, C and Tripathy, S. (2017). The initial, primary and secondary consolidation response of soft clay reinforced with granular column. Part 1: Under widespread loading. Submitted to Geotechnique. 
Slocombe, B.C., Bell, A.L. and Baez, J.I. (2000). 'The densification of granular soils using vibro methods'. In: Geotechnique, 50(6), pp. 715-725.

Watts, K.S., Johnson, D., Wood, L.A. and Saadi, A. (2000). 'An instrumented trial of vibro ground treatment supporting strip foundations in a variable fill'. In: Geotechnique, 50(6), pp. 699-708.

Weber, T.M., Plotze, M., Laue, J., Peschke, G. and Springman, S.M. (2010). 'Smear zone identification and soil properties around stone columns constructed in-flight in centrifuge model tests'. In: Geotechnique, 60(3), pp.197-206 
Table 1: Physical Properties

\begin{tabular}{|l|l|}
\hline \multicolumn{2}{|c|}{ Kaolin } \\
\hline Liquid limit \% & 71 \\
\hline Plastic Limit \% & 32 \\
\hline Angle of internal friction & 22 \\
\hline Organic content \% & 0 \\
\hline & Sleech \\
\hline Liquid Limit \% & 49 \\
\hline Plastic Limit \% & 21 \\
\hline Natural water content \% & 38 \\
\hline Angle of internal friction & 30 \\
\hline Organic content \% & 8 \\
\hline
\end{tabular}


Table 2: Initial, consolidation settlement and creep rate

\begin{tabular}{|c|c|c|c|c|c|c|}
\hline & & \multicolumn{5}{|c|}{ Loading increment $(\mathrm{kPa})$} \\
\hline & & 60 & 120 & 180 & 240 & 300 \\
\hline \multirow{3}{*}{$\begin{array}{c}\text { Kaolin } \\
\text { (without column) }\end{array}$} & $\Delta s_{i(n c)}$ & 0.03 & 0.04 & 0.04 & 0.08 & 0.10 \\
\hline & $\Delta s_{c(n c)}$ & 0.32 & 0.46 & 0.95 & 1.97 & 3.46 \\
\hline & $c_{\alpha(n c)}$ & 0.035 & 0.053 & 0.063 & 0.123 & 0.150 \\
\hline \multirow{6}{*}{ Kaolin (with column) } & $\Delta s_{i(c)}$ & 0.17 & 0.25 & 0.25 & 0.12 & 0.10 \\
\hline & $n_{i}$ & NA & NA & NA & NA & $\mathrm{NA}$ \\
\hline & $\Delta s_{c(c)}$ & 0.21 & 0.35 & 0.73 & 1.16 & 1.75 \\
\hline & $n_{c}$ & 1.52 & 1.31 & 1.30 & 1.69 & 1.98 \\
\hline & $c_{\alpha(c)}$ & 0.044 & 0.040 & 0.056 & 0.078 & 0.125 \\
\hline & $n_{\alpha}$ & 0.80 & 1.40 & 1.25 & 1.58 & 1.20 \\
\hline \multirow{3}{*}{$\begin{array}{c}\text { Sleech } \\
\text { (without column) }\end{array}$} & $\Delta s_{i(n c)}$ & 0.11 & 0.12 & 0.14 & & \\
\hline & $\Delta s_{c(n c)}$ & 1.32 & 1.33 & 2.42 & & \\
\hline & $c_{\alpha(n c)}$ & 0.16 & 0.20 & 0.315 & & \\
\hline \multirow{6}{*}{ Sleech (with column) } & $\Delta s_{i(c)}$ & 0.06 & 0.07 & 0.08 & & \\
\hline & $n_{i}$ & NA & NA & NA & & \\
\hline & $\Delta s_{c(c)}$ & 0.55 & 0.58 & 0.68 & & \\
\hline & $n_{c}$ & 2.46 & 2.37 & 3.80 & & \\
\hline & $c_{\alpha(c)}$ & 0.044 & 0.056 & 0.103 & & \\
\hline & $n_{\alpha}$ & 3.71 & 3.55 & 3.05 & & \\
\hline
\end{tabular}




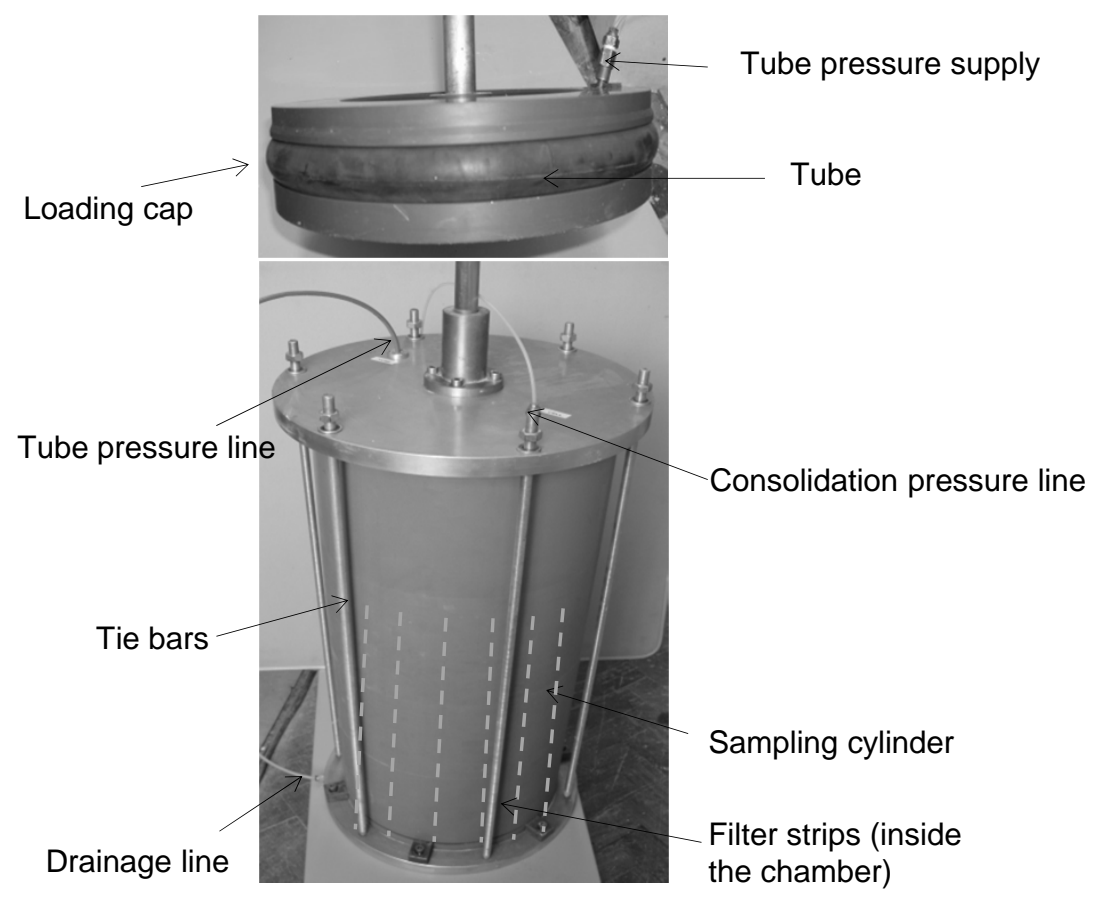

(a) Consolidation chamber

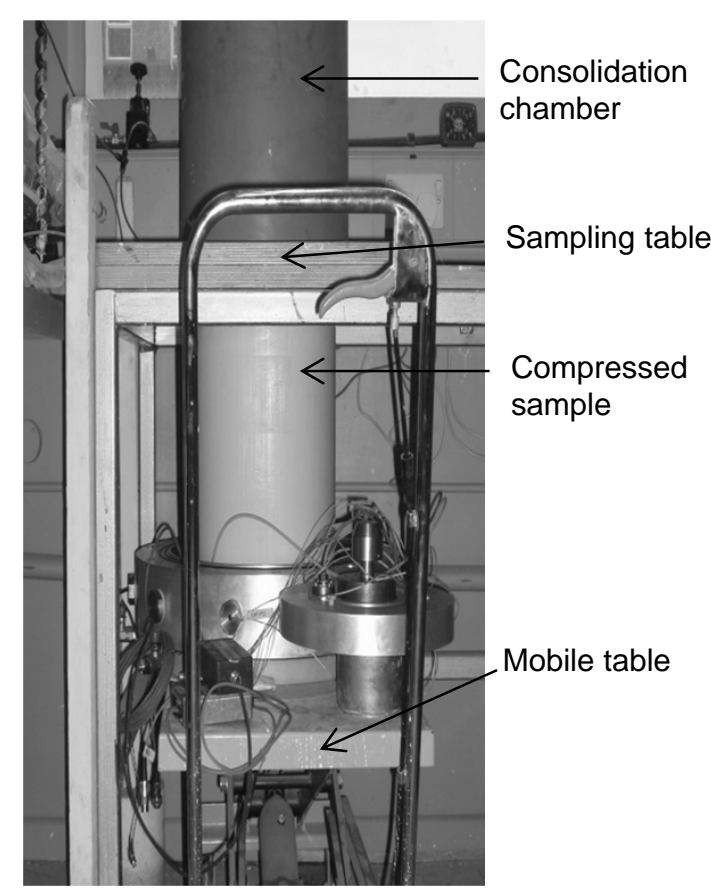

(b) Extruding sample on testing chamber

Figure 1 Sample preparation method, Black et.al. 2011 


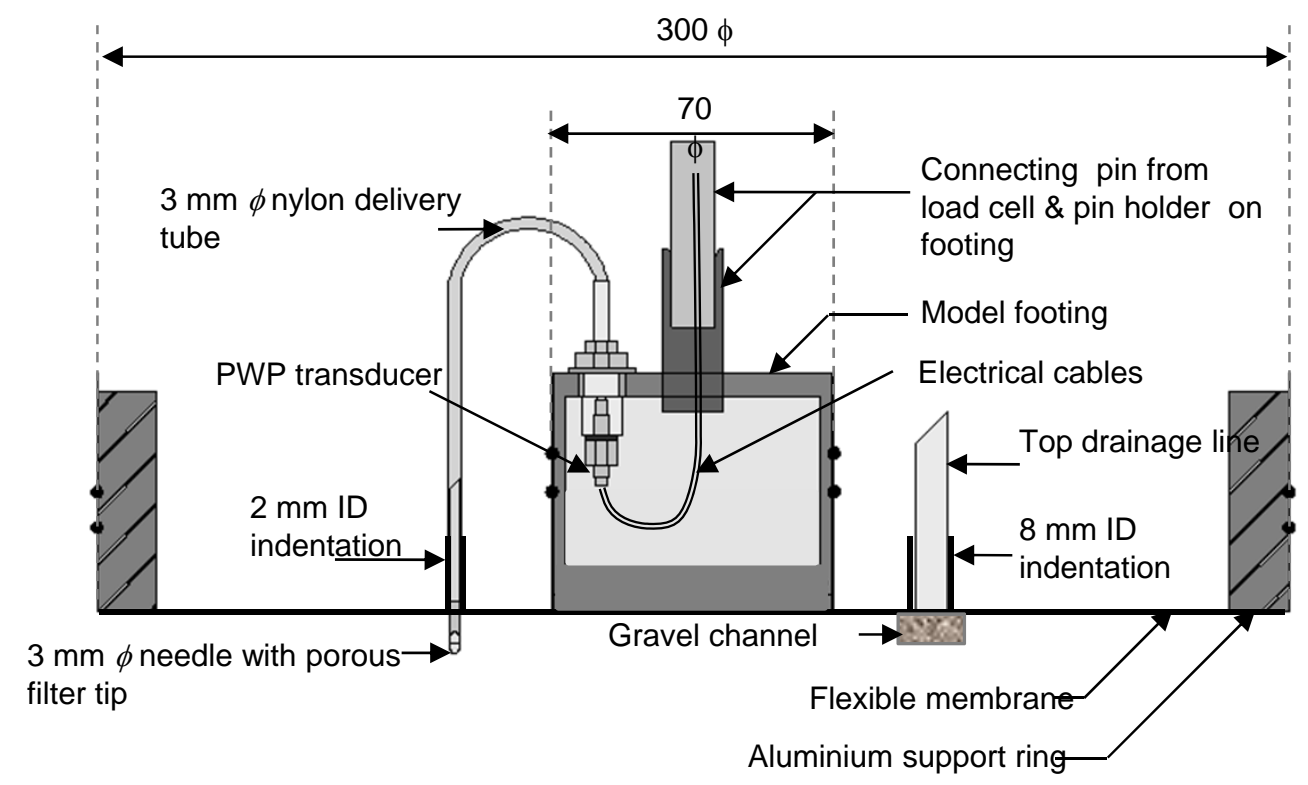

Figure 2 Schematic of footing, flexible boundary conditions and pore water pressure monitoring arrangement in proximity of the footing 


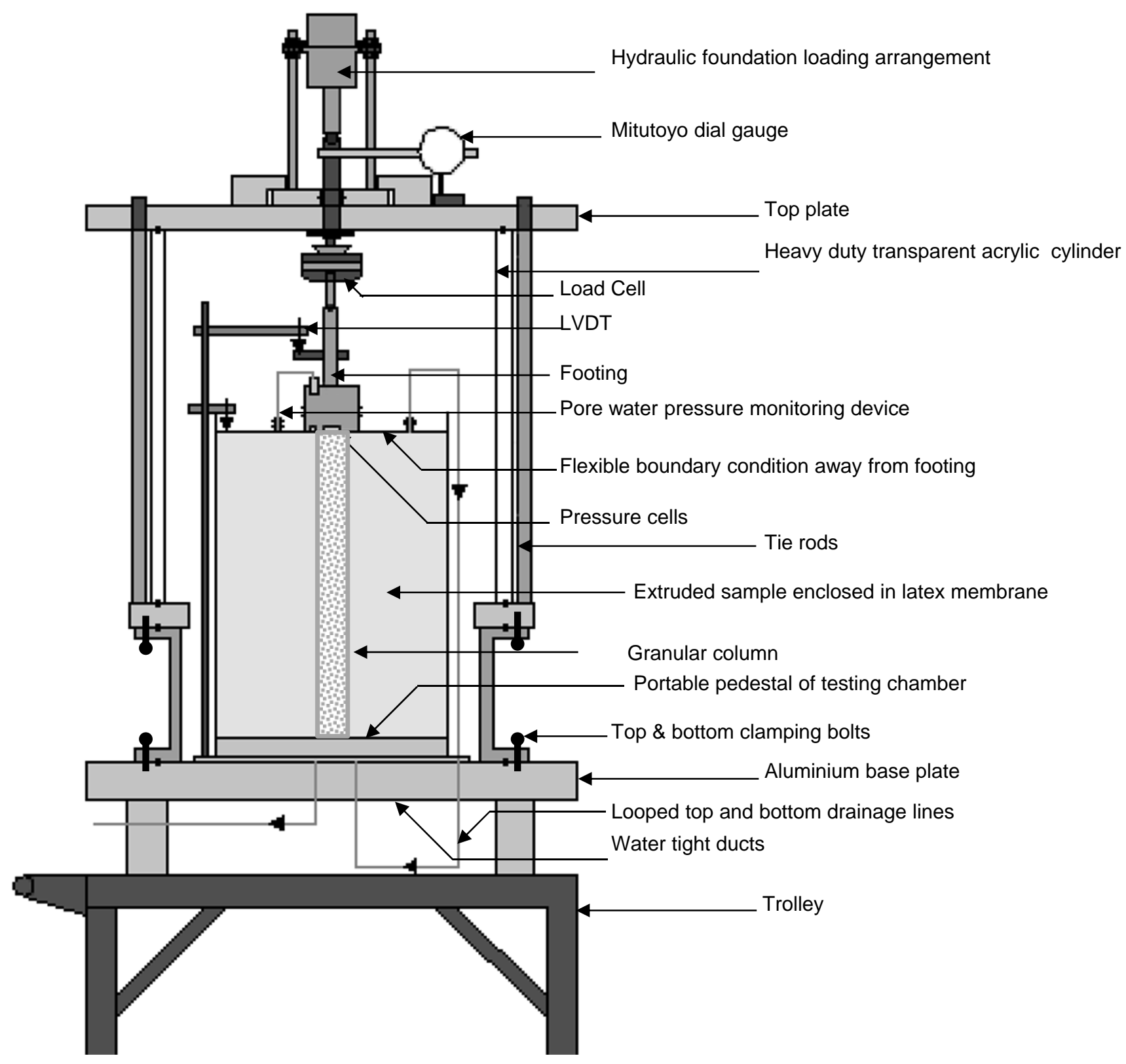

Figure 3: Simplified schematic of the assembled testing chamber 


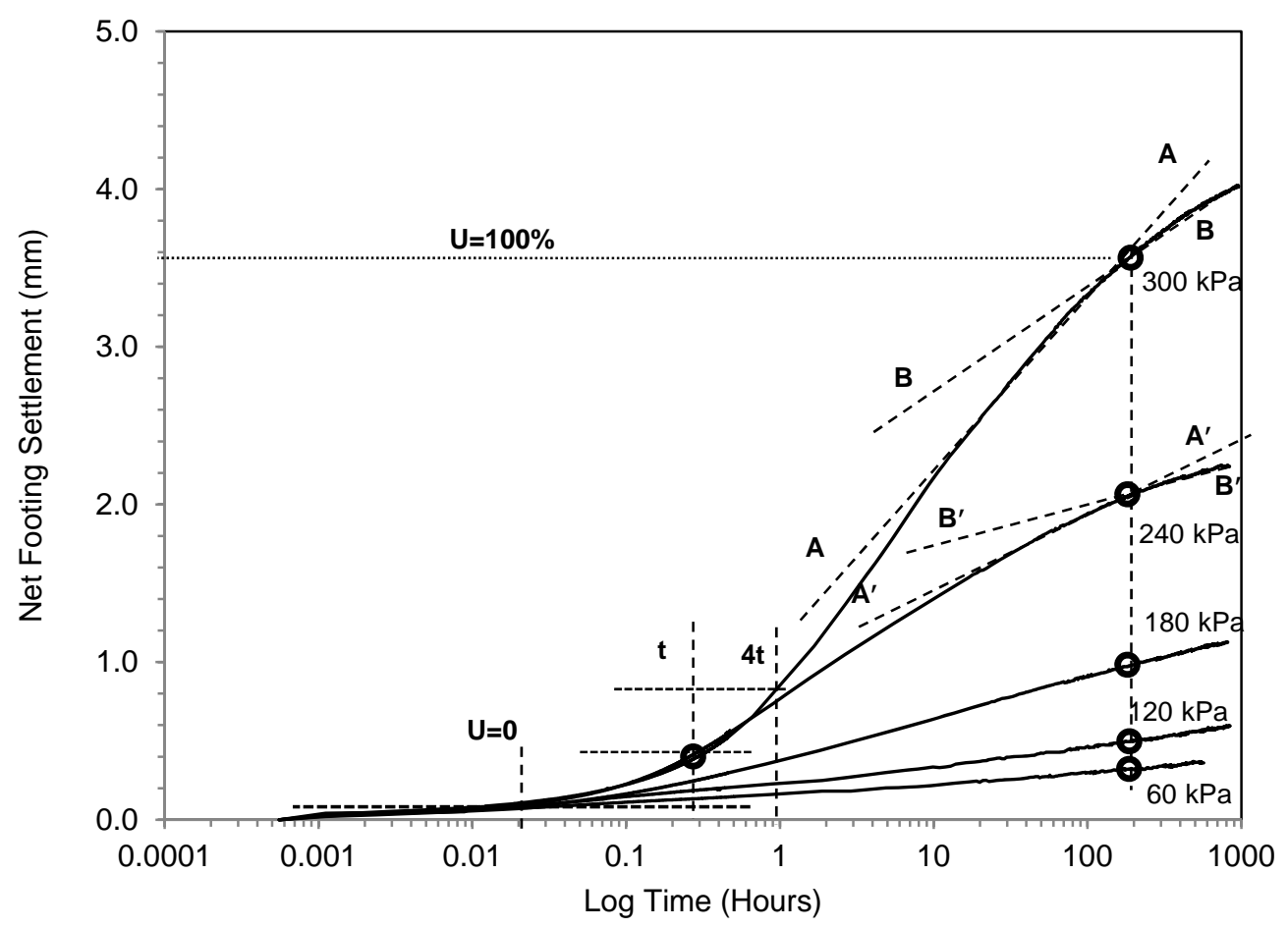

(a) Net Footing Settlement vs Log Time

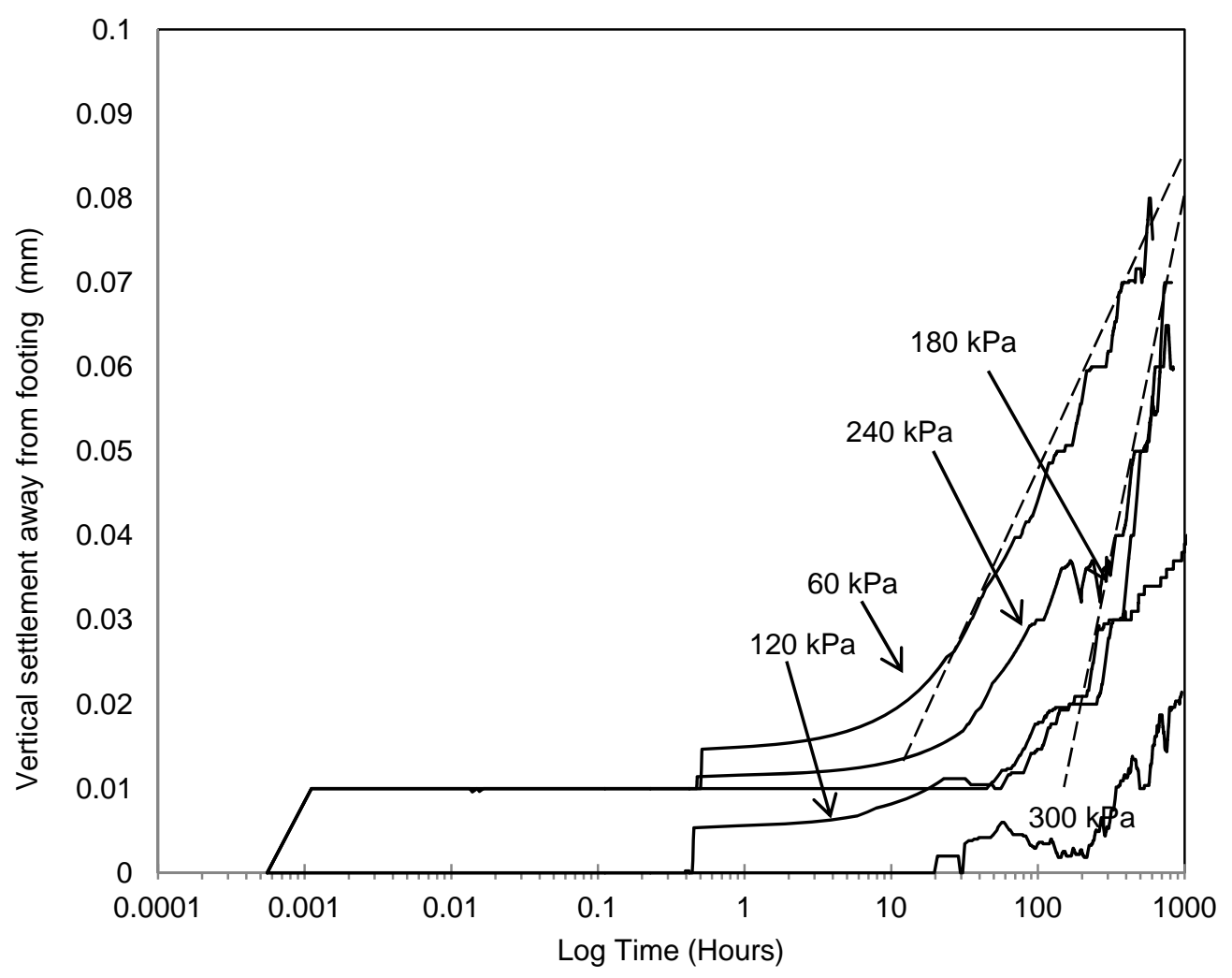

(b) Settlement away from footing vs Log Time

Figure 4: Settlement of footing (net) and away from footing for kaolin under foundation pressures of $60 \mathrm{kPa}, 120 \mathrm{kPa}, 180 \mathrm{kPa}, 240 \mathrm{kPa}$ and $300 \mathrm{kPa}$ 


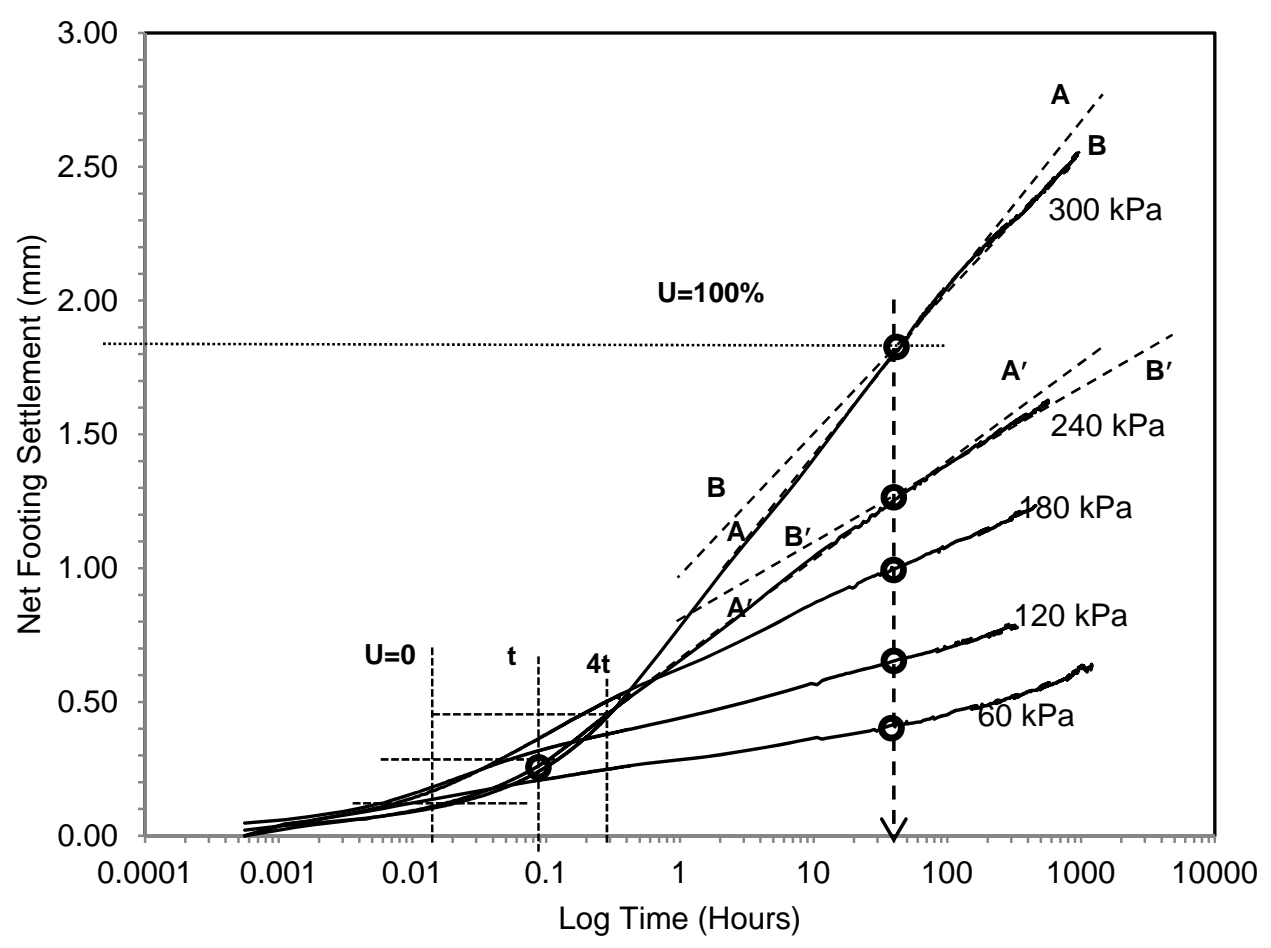

(a) Net Footing Settlement vs Log Time

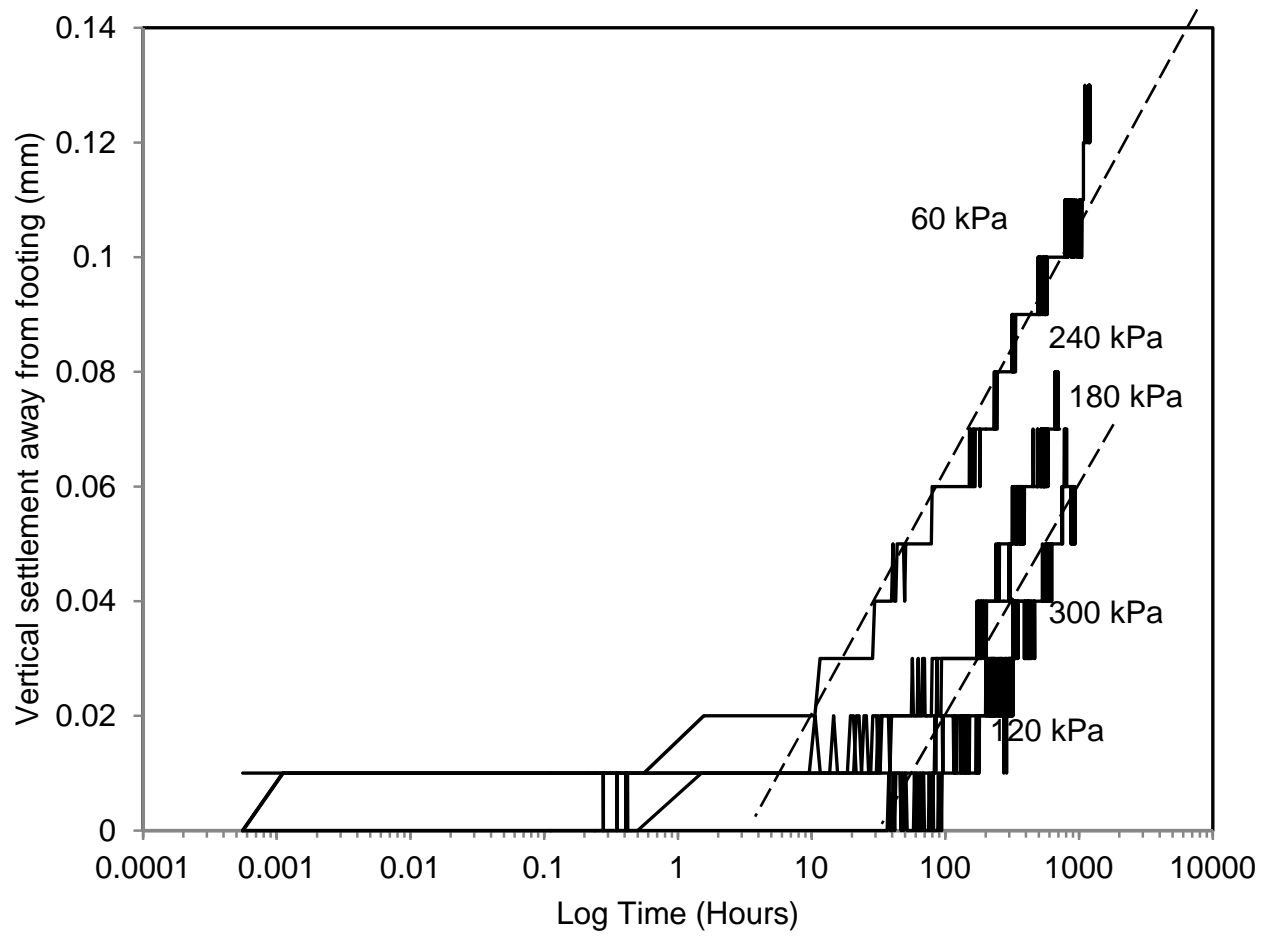

(b) Settlement away from footing vs Log Time

Figure 5: Settlement of footing (net) and away from footing for kaolin with a fully penetrating 40 $\mathrm{mm} \phi$ column under foundation pressure s of $60 \mathrm{kPa}, 120 \mathrm{kPa}, 180 \mathrm{kPa}, 240 \mathrm{kPa}$ and $300 \mathrm{kPa}$ 


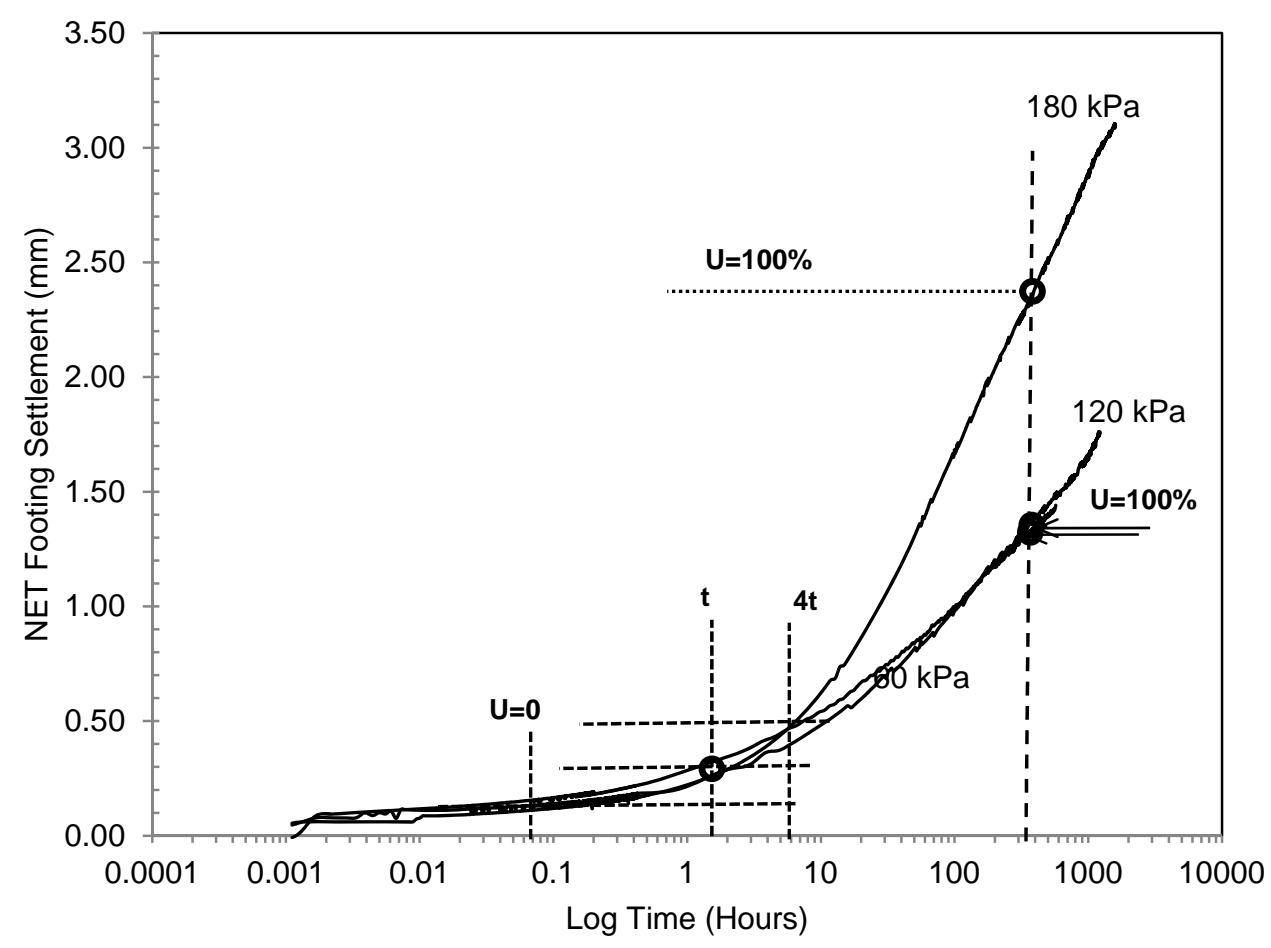

(a) Net Footing Settlement vs Log Time

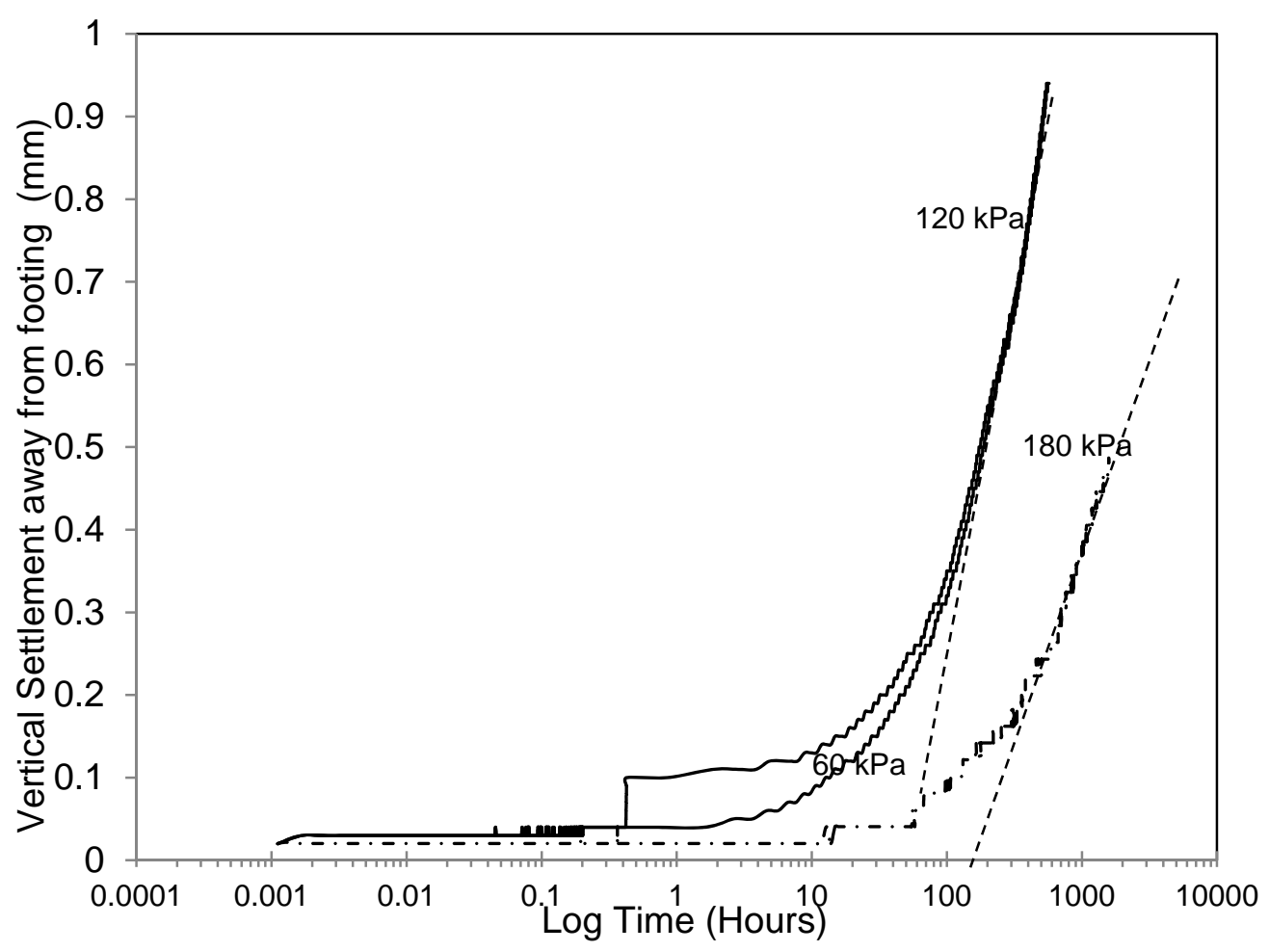

(b) Settlement away from footing vs Log Time

Figure 6 Settlement (net) of footing and away from footing for sleech under foundation pressures of $60 \mathrm{kPa}, 120 \mathrm{kPa}$ and $180 \mathrm{kPa}$ 


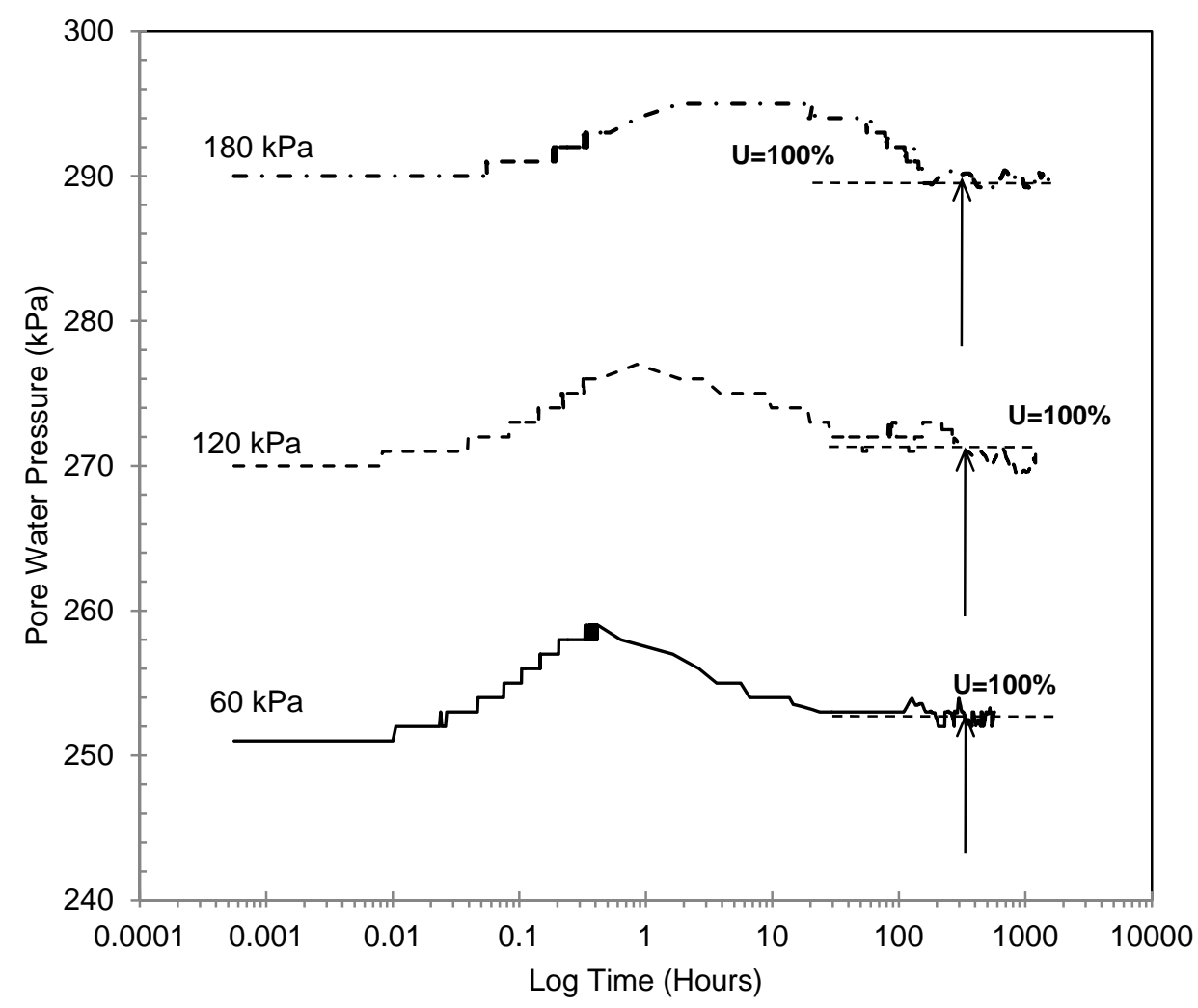

Figure 7 Pore water pressure variation with time during application of a bearing pressures of $60 \mathrm{kPa}, 120 \mathrm{kPa}$ and180 kPa for sleech 


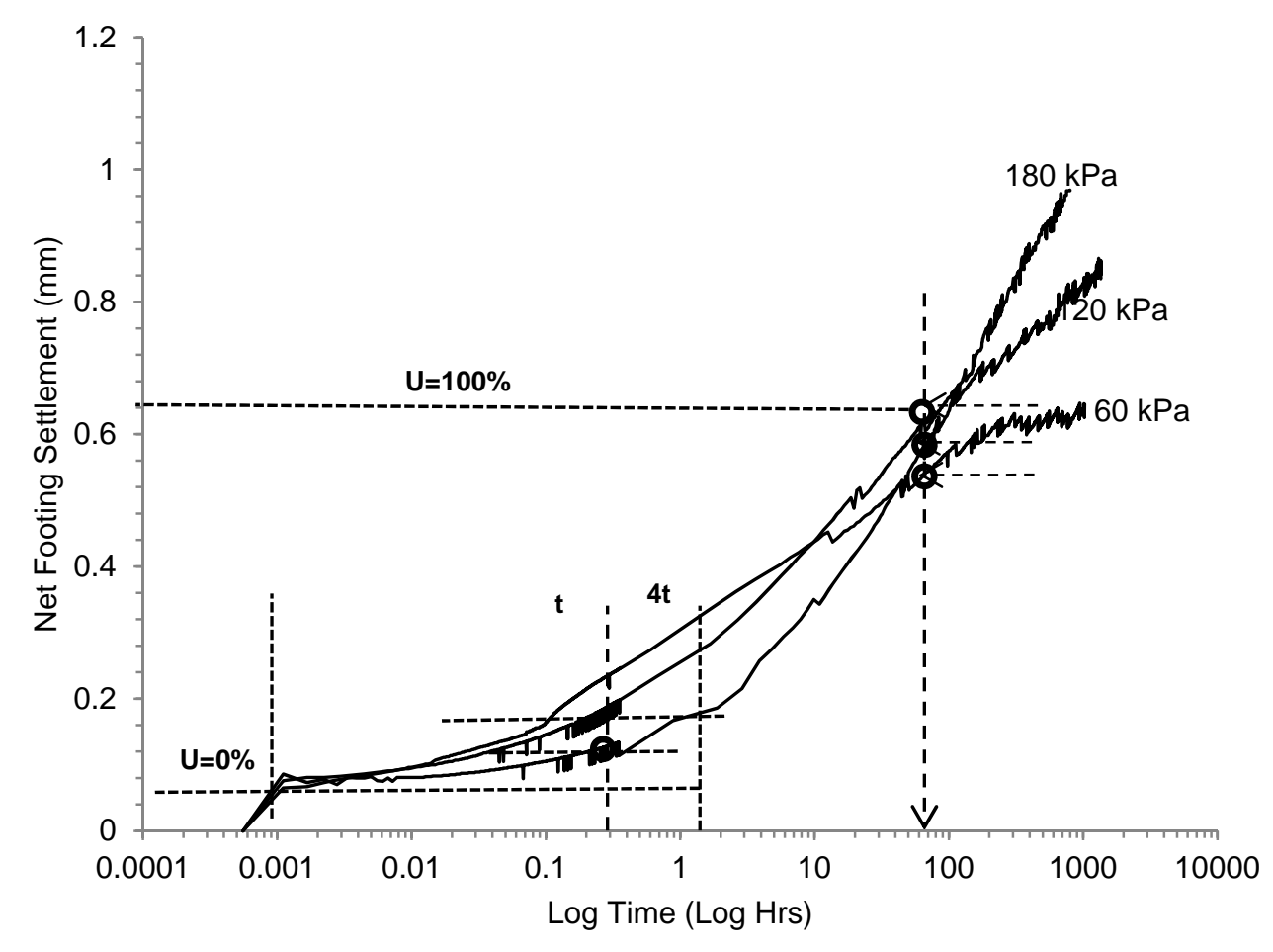

(a) Net Footing Settlement vs Log Time

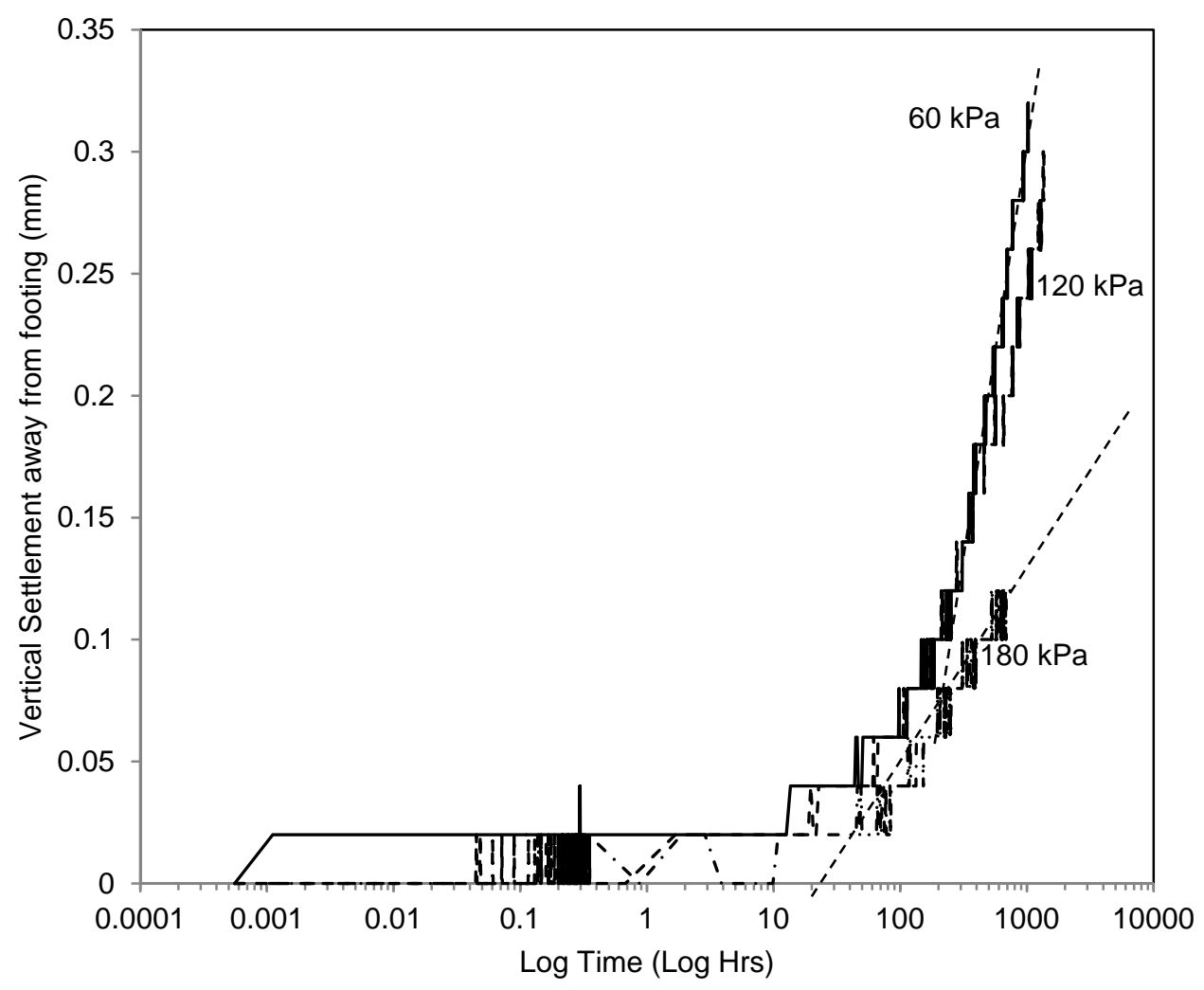

(b) Settlement away from footing vs Log Time

Figure 8: Settlement of footing and away from footing for sleech with a fully penetrating 40 $\mathrm{mm} \phi$ column under foundation pressures of $60 \mathrm{kPa}, 120 \mathrm{kPa}$ and $180 \mathrm{kPa}$ 


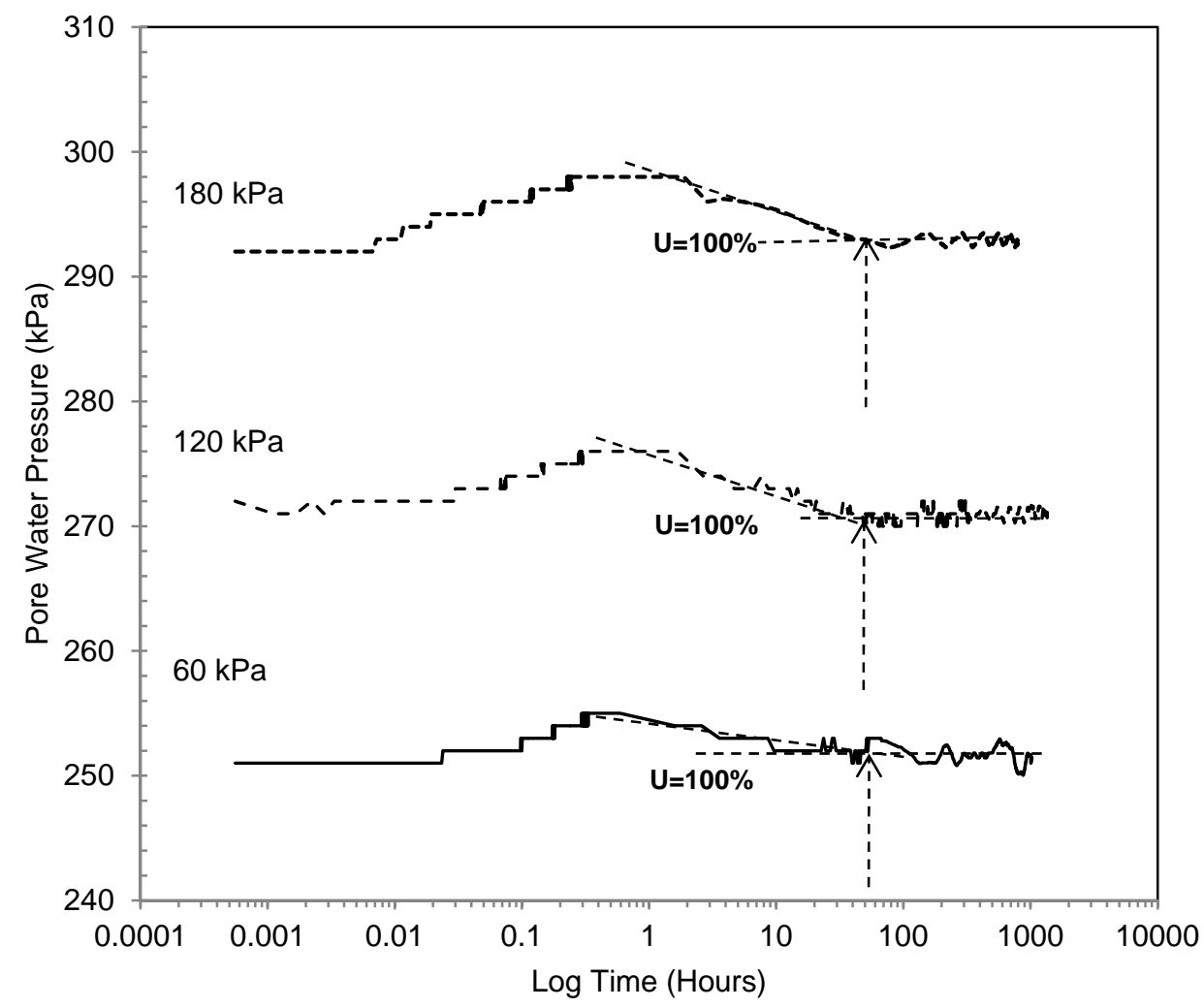

Figure 9 Pore water pressure variation with time during application of a bearing pressure $\mathrm{s}$ of $60 \mathrm{kPa}, 120 \mathrm{kPa}$ and180 $\mathrm{kPa}$ for sleech reinforced with a fully penetrating $40 \mathrm{~mm} \phi$ column 


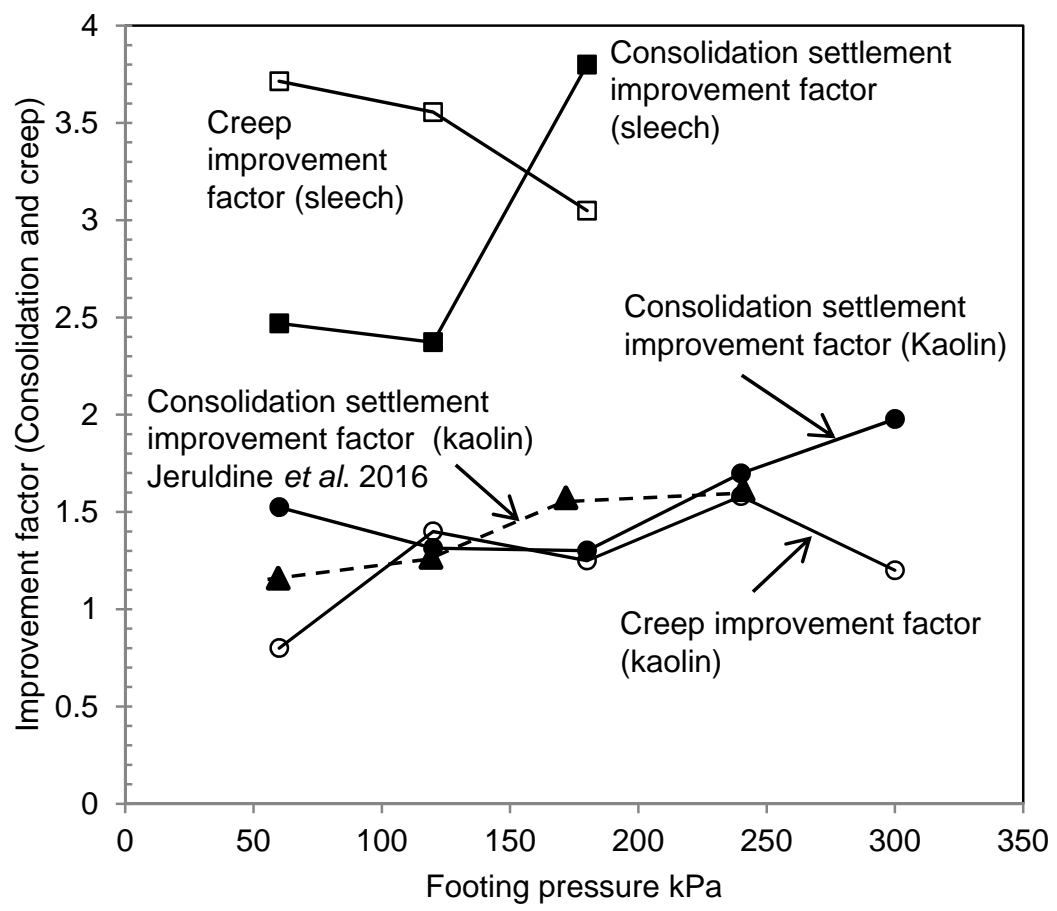

Figure 10 Settlement improvement factor 


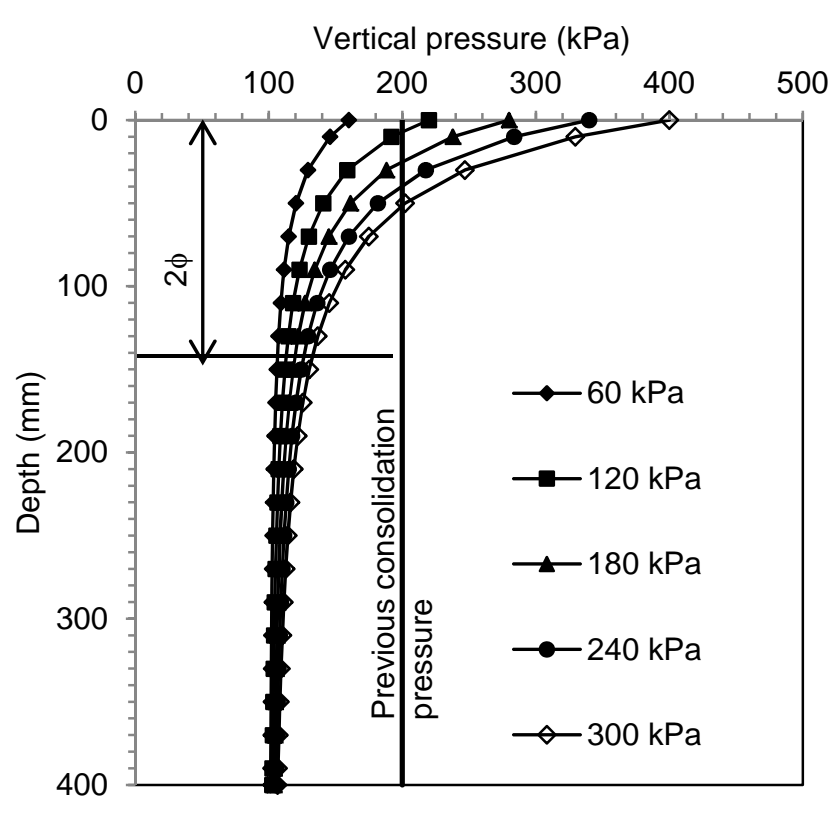

(a) Kaolin

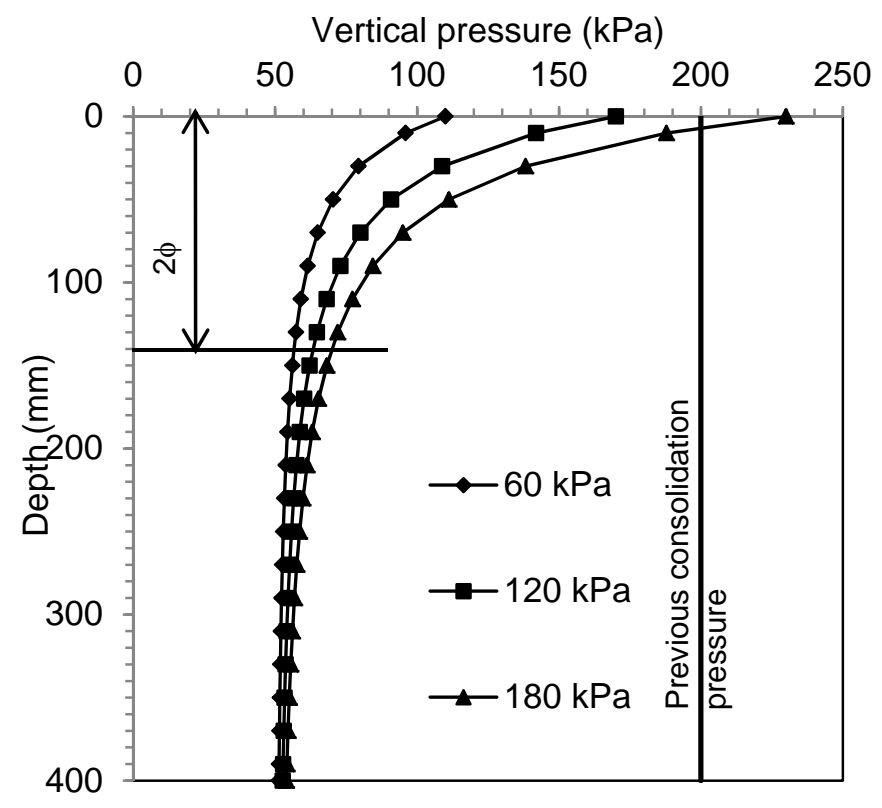

(b) Sleech

Figure 11: Pressure distribution under the footing using simple 2:1 spread 


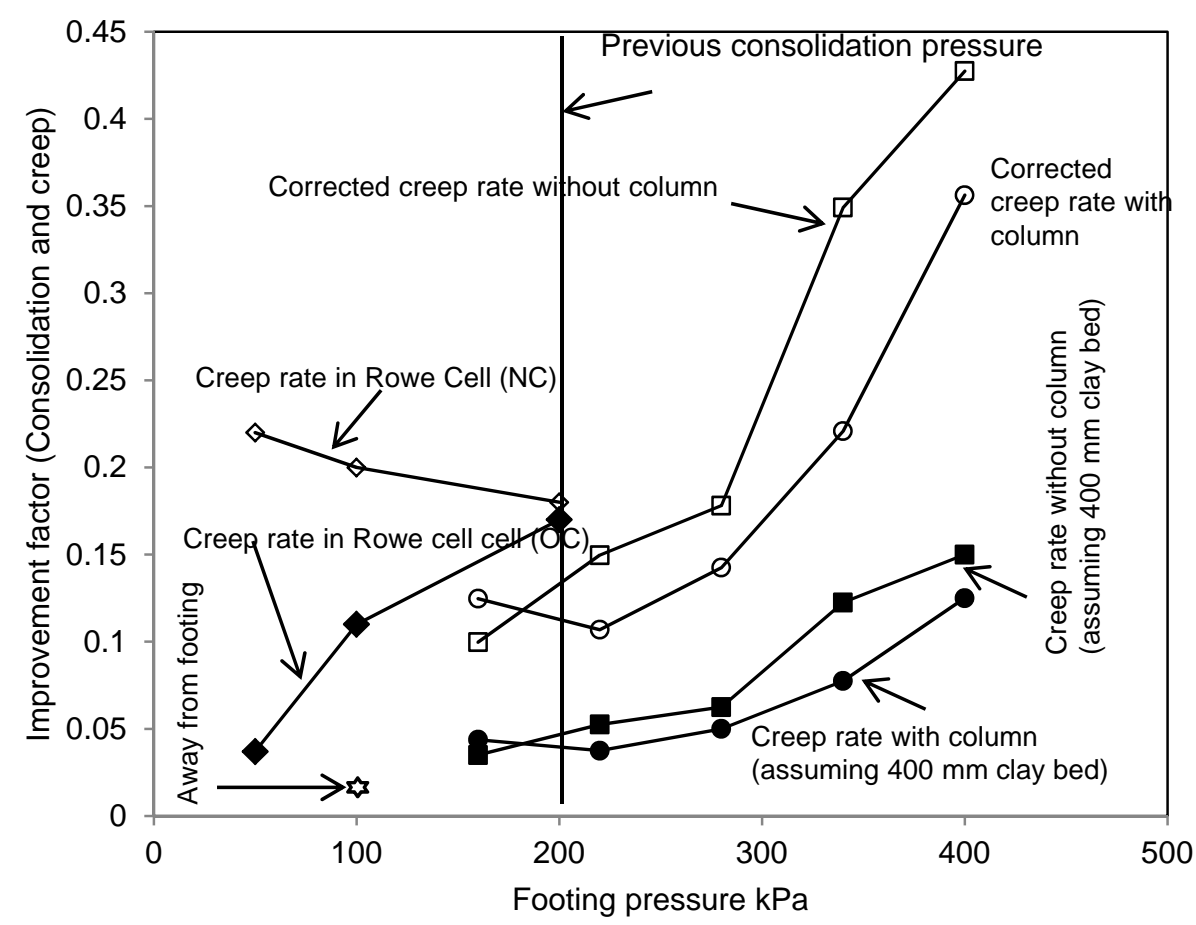

(a) kaolin

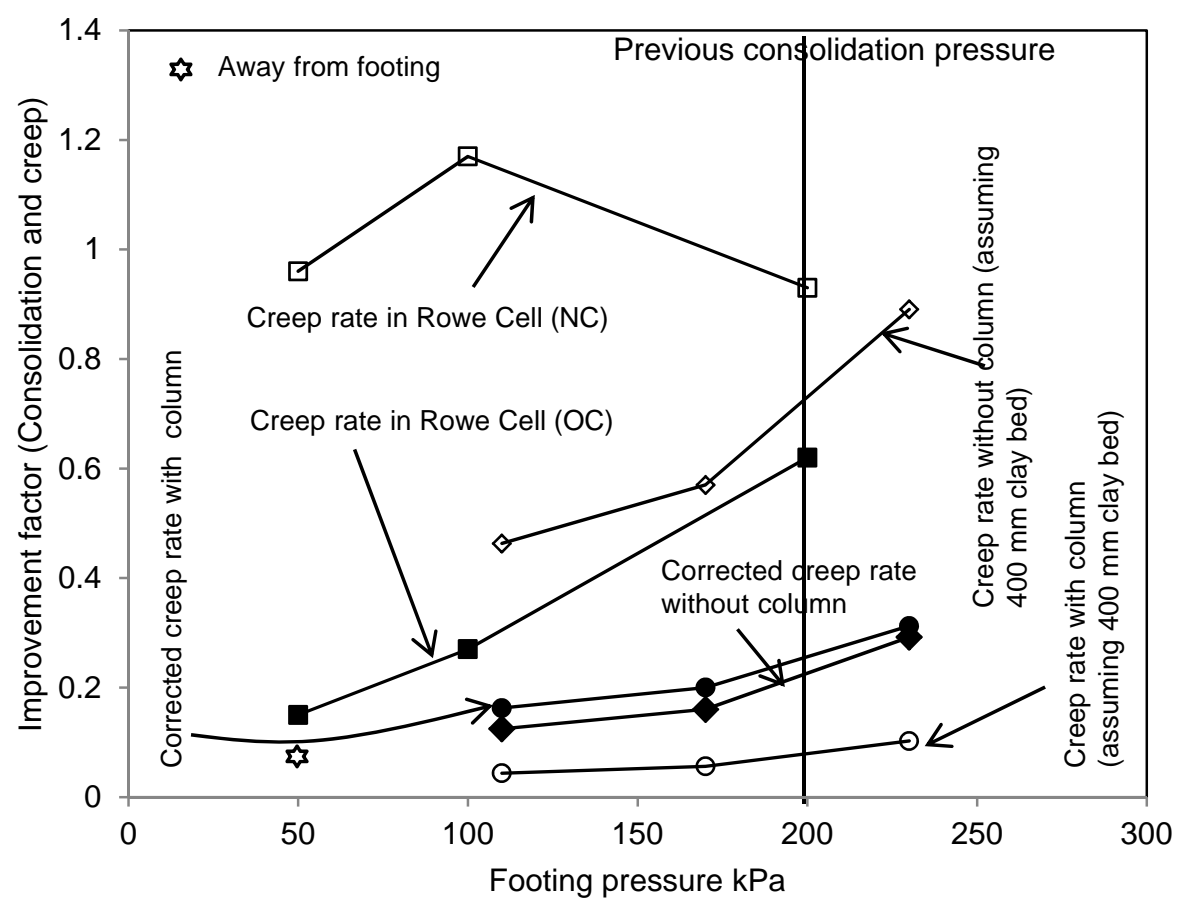

(b) Sleech

Figure 12: Creep rate for kaolin and sleech under various stress conditions 